\title{
The Brazilian Amazon's Double Reversal of Fortune
}

\author{
Robin Burgess* $\quad$ Francisco J. M. Costa ${ }^{\dagger} \quad$ Benjamin A. Olken ${ }^{\ddagger}$
}

August 7, 2019

\begin{abstract}
We use high-resolution satellite data to determine how Amazonian deforestation changes discretely at the Brazilian international border. We document two dramatic reversals. In 2000, Brazilian pixels were 37 percent more likely to be deforested, and between 2001 and 2005 annual Brazilian deforestation was more than three times the rate observed across the border. In 2006, just after Brazil introduced policies to reduce deforestation, these differences disappear. However, from 2014, amid a period of economic crisis and deteriorating commitment to environmental regulation, Brazilian deforestation rates jump back up to near pre-reform levels. These results demonstrate the power of the state to affect whether wilderness ecosystems are conserved or exploited.
\end{abstract}

We would like to thank João Amaro, Nick Cerkez, Víctor Quintas-Martínez, Gabriel Mesquita and Christiane Szerman for excellent research assistance, and Jonathan Colmer, Dave Donaldson, Thiemo Fetzer, Michael Greenstone, Torfinn Harding, Kelsey Jack, Seema Jayachandran, Mushfiq Mobarak, Imran Rasul, Dimitri Szerman, Matthew Turner, Andre Villela, and Tom Vogl for helpful comments. We also thank participants at LSE Conference on Environmental and Developmental Economics, NBER EEE Program Meeting, RIDGE POL Forum, and the Economics of Low Carbon Markets Conference. Burgess gratefully acknowledges financial support from the European Research Council Grant 743278 "Man and Nature in Developing Countries" and Costa from Rede de Pesquisa Aplicada FGV and CAPES/Brasil (Grant \#001).

*London School of Economics. E-mail: r.burgess@lse.ac.uk.

${ }^{\dagger}$ FGV EPGE. E-mail: francisco.costa@fgv.br.

${ }^{\ddagger}$ MIT. E-mail: bolken@mit.edu. 


\section{Introduction}

This paper explores the degree to which national policies can exert regulatory control over conservation by examining whether there are discrete changes in deforestation at national borders. Because political and hence policy jurisdictions stop at the national border - but satellite data on conservation outcomes can be measured uniformly across the geography - by analyzing satellite data on deforestation at the international border we can precisely isolate the effect of national policies, holding constant the underlying geography.

We do so in the context of one of the most important global ecosystems: the Amazon rainforest. Covering more than two million square miles - about the size of the contiguous United States west of the Mississippi River - the Amazon plays a crucial role in the global carbon cycle and hosts an astounding amount of biological diversity. The Amazon is a global public good - its immense size implies that the rate at which it is deforested will affect the pace of global warming (IPBES, 2018). Hence understanding whether conservation efforts by Amazonian nation states are effective is an issue of international importance. Indeed if these national policies have no de facto bite then this renders ineffective both national and international accords to slow Amazonian deforestation (Fearnside, 2012).

To study the impact of national policy in the Amazon, we use newly-updated annual 30-meter resolution Landsat 7 data which allows us to monitor deforestation in a consistent manner over time and space from 2000 to 2018 (Hansen et al., 2013). The high resolution allows us to zoom in close to the border to identify precise effects - our preferred specification uses a bandwidth of only $25 \mathrm{~km}$ on either side of the national border. We show that areas on both sides of the border look similar in most important geographic respects, such as slope and distances to urban areas, water, and roads. This is to be expected given that historical borders were drawn with little regard to local institutions and with limited knowledge of the underlying geographies. While our focus is on results analyzing the entire $12,800 \mathrm{~km}$ Brazilian border in the Amazon, we perform a robustness exercise restricting attention to "artificial borders" - i.e., typically straight lines drawn in unknown territory by former colonizers and which do not correspond to any preexisting natural or institutional border (Alesina et al., 2011).

We investigate the role of national regulation of deforestation by running spatial regression discontinuity designs, using as running variable the distance to the Brazilian national border. This paper therefore fits within a rich literature using borders to look at policy effects. ${ }^{1}$ We document five striking facts. First, we show that up until about 2005, the level and rate of deforestation was dramatically higher on the Brazilian side of the

\footnotetext{
${ }^{1}$ While borders have been shown to be associated with policy outcomes in developed countries (Black, 1999; Holmes, 1998; Turner et al., 2014) where regulations are tightly enforced, the evidence in developing countries is more mixed (Michalopoulos and Papaioannou, 2014; Pinkovskiy, 2017).
} 
border than in its neighbors. This was associated with Brazilian policies to develop the Amazon. When our data starts in 2000, Brazilian land was 37 percent more likely to be have been deforested than similar lands located just a few kilometers away across the border. From 2001 to 2005, the annual deforestation rate was more than three times higher on the Brazilian side of the border than in neighboring countries. These differences are similar across the borders with both Bolivia and Peru - the two border segments where the so-called "Arc of Deforestation" intersects the international border - indicating that the differences are due to policies in Brazil, rather in countries across the border.

Second, we show that the discontinuity in deforestation rates disappears precipitously in 2006 - just as Brazil was implementing substantially tougher national policies targeting illegal deforestation. In November 2004, Brazil launched the Action Plan for the Prevention and Control of Deforestation in the Legal Amazon (PPCDAm) which strengthened the legal penalties associated with illegal deforestation, particularly on unclaimed and private land outside protected areas (Nepstad et al., 2009). PPCDAm was bolstered in 2006 by the Law on Public Forest Management, and by the Center for Environmental Monitoring becoming fully operational, which together enabled the Brazilian state to couple satellite-based detection of deforestation with police and army enforcement operations targeted at areas where illegal deforestation had been detected (MMA, 2008).

Third, we document that the positive impacts of the Brazilian forest policy were relatively short-lived. Starting in 2014, deforestation rates in Brazil have started to return to near pre-2004 levels. Again, we find discontinuously higher deforestation that goes right up to the international border but not across it, which suggests that these changes were caused by Brazilian policies. This second reversal coincides with a period of economic crisis and lowered commitment to environmental regulation with many of the regulatory changes brought in by PPCDAm being undone (Ferreira et al., 2014). Most notably, the New Forest Code enacted in late 2012, and disputed in the Supreme Court until 2018, set an amnesty for "small" properties that had deforested Legal Reserve areas before 2008 - in practice, forgiving 90 percent of the rural properties in the area for engaging in crimes of illegal deforestation (Soares-Filho et al., 2014). This reversal is consistent with the hypothesis that environmental protection was weakened and reversed under political pressure (Fearnside, 2016; Azevedo et al., 2017; Freitas et al., 2018; Soterroni et al., 2018). Newly released satellite data therefore allows us to document this widespread reversal across the Brazilian Amazon, and in particular, our border analysis shows that this is a uniquely Brazilian phenomenon. This is concrete evidence that the Brazilian state is now favoring exploitation over conservation.

Fourth, we show that de jure land use restrictions on the Brazilian side matter - even at the border. We find that areas designated as protected areas in Brazil have always been less deforested than unprotected lands just on the opposite side of the international 
border, and this remains the case from 2006 onward. The Brazilian state was therefore able to enforce environmental regulations when there was the political will to do so even in these outlying areas. Instead, reductions in deforestation following the mid-2000s policy changes in Brazil were most pronounced on unclaimed and private lands outside protected areas - precisely the types of lands where the increase in enforcement by the Brazilian state was most pronounced (Appendix B.3).

Fifth, we find that the Brazilian effort to cope with illegal deforestation was effective to reduce forest loss exactly in those areas closer to economic activity, at least initially. We further document that while the effects of Brazilian deforestation policy started to weaken first in areas further from enforcement bases (in the middle tercile of distance, between 560-880km away from enforcement centers), by 2015 the impact of Brazilian deforestation policies was severely undermined even in areas closer to law enforcement. In sum, in the first reversal Brazilian effort to cope with illegal deforestation was effective in reducing forest loss exactly in those areas closer to economic and market pressure and to law enforcement bases. However, as the policy position towards environmental regulation shifted in Brazil it was precisely these areas that experienced accelerated deforestation during the second reversal.

Combined, these results - the sharp discontinuity in deforestation levels and rates at the border, the dramatic change in deforestation at the border when then national government cracked down, the fact that protected areas in Brazil were always less likely to be deforested than corresponding lands just across the national border, and the reversal of deforestation rates exactly in the areas where environmental policies were previously highly enforced - demonstrate the remarkable reach of the Brazilian state to exploit or conserve its natural resources. They suggest that the rapid deforestation in the Brazilian Amazon in the early 2000s was a consequence of a pro-exploitation policy environment. This policy stance was sharply reversed in the 2006-2013 period with laws to protect the Amazon rainforest being introduced and enforced. This position stalled and reversed in the post-2013 period during a period when political and economic crisis collided with a weakening of forest conservation laws.

Our results help to understand why the Brazilian Amazon was the only major area of tropical forest that has experienced falling rates of deforestation since the mid-2000s (Figure 1), and why this downward trend has reversed during the past few years. Brazil - which contains 65 percent of the Amazon rainforest - moves from having almost the highest rate of deforestation in 2001 to having the lowest rate in 2013, with the trend reversal occurring in the mid-2000s (see, e.g., Nepstad et al., 2009; Nolte et al., 2013; Godar et al., 2014). In strict contrast Indonesia, the Democratic Republic of Congo and the non-Brazilian Amazon (which contain the bulk of the remaining tropical forest) experience rising deforestation rates across the 2001-2018 period. Identifying the role of 
Brazilian government policies in causing this decline in deforestation - and its subsequent increase - is challenging as these policies were applied throughout the country. The same challenge applies to understanding why this trend reversed from 2014 onwards. ${ }^{2}$ By zooming in on the national border, where Brazil's policy reach ends, we can precisely identify the limits and impacts of being in Brazil and under the Brazilian policy regime. ${ }^{3}$ The methods employed here therefore may be usefully employed by governments concerned with wilderness conservation in other contexts.

The remainder of this paper is organized as follows. Section 2 sets our empirical specification and discusses our data. We present results in Section 3. Section 4 concludes.

\section{Empirical methods and data}

\subsection{Empirical specification}

Our empirical analysis takes place at the 120 -meter pixel resolution level. ${ }^{4}$ Our running variable is distance to the border. Positive distances represent pixels in the Brazilian Amazon, while negative distances represent pixels in the Amazon outside Brazil.

Our main estimating equation is

$$
Y_{i}=\alpha+\gamma \text { Brazil }_{i}+f\left(\text { DistBorder }_{i}\right)+\delta X_{i}+\varepsilon_{i}
$$

where $Y_{i}$ is the outcome of interest (forest cover in 2000 or forest loss in a given year) in pixel $i$. Brazil $l_{i}$ is a dummy equal to one if pixel $i$ is in Brazil. $f\left(\right.$ DistBorder $\left._{i}\right)=$ Brazil $_{i} * f^{\text {Brazil }}\left(\right.$ DistBorder $\left._{i}\right)+\left(1-\right.$ Brazil $\left._{i}\right) * f^{\text {OutsideBrazil }}\left(\right.$ DistBorder $\left._{i}\right)$ is a polynomial of distance from the border, separately on each side of the border. Following Gelman and Imbens (2019), we use separate linear polynomials $f$ on each side of the border for our preferred specification, and use separate quadratic polynomials as robustness. $X_{i}$ is a vector of controls explained below. We cluster standard errors in blocks of size $25 \mathrm{~km}$ by $25 \mathrm{~km}$ to allow for geographical spatial error correlation. ${ }^{5}$

The coefficient of interest is $\gamma$, which measures the difference in the share of a pixel

\footnotetext{
${ }^{2}$ Several papers use variation across Brazilian municipalities for identification. Assunção et al. (2013) compare areas with more or less cloud cover to argue that satellite-based enforcement contributed to reductions in deforestation, Assunção et al. (2015) compare municipalities with greater or lower "tightness of land constraints" for farmers and Godar et al. (2014) shows that the decline in deforestation is larger in census tracts dominated by large landholders.

${ }^{3}$ A related literature studies how regulation and infrastructure affect deforestation (e.g., Adman, 2014; Souza-Rodrigues, 2018; Anderson et al., 2016; Asher et al., 2017) and violence in the Amazon (e.g., Chimeli and Soares, 2017).

${ }^{4}$ We aggregate from the 30 -meter to 120 -meter level to ease computational constraints.

${ }^{5}$ Conley (1999) standard errors would be an alternative but is computationally challenging due to the extremely large number of observations. Our OLS results show bias-corrected confidence intervals (Calonico et al., 2014).
} 
that is forested in 2000, or deforested in a given year after 2000, on the Brazilian side of the border compared to the other side. We estimate equation (1) by OLS in our main specifications. When we perform exercises to assess if there is heterogeneity in institutional effects across different segments of the border and land types within Brazil, we estimate equation (1) using a Poisson model with cluster-robust standard errors clustered at the same $25 \mathrm{~km}$ by $25 \mathrm{~km}$ blocks. ${ }^{6}$ We do this because there are substantial differences in baseline magnitudes of deforestation across the Amazon across land types, and Poisson estimates remain interpretable as percent changes across land types. ${ }^{7}$

Our identifying assumption is that other factors that might affect deforestation change smoothly across national borders. If this assumption is valid, by controlling for a polynomial in distance from the border, we remove additional sources of biases and allow for causal inference. The idea that the borders are largely arbitrary is consistent with the historical evidence - they were largely set by the 1750 Treaty of Madrid (see Appendix B.3.4) when many of these areas deep in the jungle were largely unexplored and appeared as blank spaces labeled "unknown country" in maps from that time (Furtado, 2012).

To explore this assumption in the data, we check for discontinuities at the border on four factors that may influence deforestation: slope, distance to water, distance to urban areas, and distance to roads. Appendix Table A2 shows the estimates of $\gamma$ which represent the discontinuous change in the level of these variables at the Brazilian border, for various subsets of the border and bandwidths. Overall, columns 1, 4, 7, and 10 show that that these factors are smoothly distributed around the Brazilian border (the remaining columns are for robustness subsamples we discuss in more detail in Section 3.1). Nonetheless, in our main specification we estimate (1) controlling for natural covariates: land, slope, and distance from water. We present results both without any controls and including additional controls for distance to infrastructure in the robustness tables.

We report results using bandwidths around the border ranging from $11 \mathrm{~km}$ to $100 \mathrm{~km}$. Since we have several dependent variables, we do not have a single theory-driven optimal bandwidth. We calculate the optimal bandwidth for each dependent variable as in Calonico et al. (2014) and in Imbens and Kalyanaraman (2012). To ease comparability across equations, our preferred bandwidth is the average of the optimal bandwidths calculated across all variables using Imbens and Kalyanaraman (2012) method, which is 25 $\mathrm{km}$ from the border. We also present results using Calonico et al. (2014) method, which is $11 \mathrm{~km}$ from the border. In our preferred specification using all $120 \mathrm{~m}$ pixels within 25 $\mathrm{km}$ of the border, we have 1,094 clusters and 31,071,838 observations each year.

\footnotetext{
${ }^{6}$ Since each $120 \mathrm{~m}$ pixel is comprised of sixteen 30 -meter pixels, our dependent variable is effectively a count variable with range $[0,16]$.

${ }^{7}$ While we present OLS results in our main specifications for ease of interpretation, Poisson results are qualitatively very similar. See Appendix Table A5, column 3, and note that that Poisson results are interpretable as percent changes in the dependent variable.
} 


\section{$2.2 \quad$ Data}

Hansen et al. (2013) worked with Google Earth Engine to detect deforestation using Landsat 7 data, resulting in a map of global forest cover in 2000 and consistent longitudinal annual forest measures. We use the latest version of this data, which has annual deforestation measures from 2001 to 2018, at a spatial resolution of 30 meters across the whole earth. The forest cover map is constructed for 2000 because Landsat 7 was launched in the previous year, so Hansen uses it as the base cover on which he constructs annual forest loss. Importantly, since this dataset is worldwide and does not use any national data as inputs, we can examine deforestation rates on both sides of the border using an exactly comparable metric. We aggregate pixels to create a resolution of $120 \times 120$ meters to facilitate computations. Annual forest loss is defined as the share of $30 \mathrm{~m}$ Landsat pixels within our $120 \mathrm{~m}$ pixels deforested within one year. Forest cover in 2000 is the average tree cover canopy of the Landsat pixels. Summary statistics are shown in Appendix Table A1.

We limit our analysis to the Amazon area as defined by RAISG (La Red Amazónica de Información Socioambiental Georreferenciada), taking into account the biome and the legal Amazon limits as defined by the various countries in the region. On net, we have more than 277 million observations in the Amazon each year.

Figure 2 shows an example of the data, displaying forest cover as of 2000. Panel (a) shows the entire Amazon, and Panel (b) zooms in on one particular border segment, which consists largely of straight lines. The substantially higher deforestation on the Brazilian (right-hand) side of the border is visible.

We supplement this deforestation data with a variety of other data sources. Hydrology data from 2000 was extracted from Google Earth Engine. Remaining data including administrative boundaries, protected areas, elevation, slope, waterways, roads and urban areas were extracted from OpenStreetMap's API.

\section{Results}

\subsection{Deforestation as of 2000}

We begin by examining the level of forest cover in 2000, the year our data begins. Figure 3 shows the percentage of forest cover in the year 2000 averaged by eighty equal-sized bins of distances from the Brazilian border, up to one hundred kilometers from each side of the border. The sharp discontinuity in deforestation is visually apparent: forest cover drops sharply exactly at the national border.

Our regression estimates using equation (1) indicate that this discontinuous change in forest cover at the border is sizable and statistically significant. Using a 25km bandwidth, 
forest cover in the Brazilian Amazon was around 3.9 percentage points smaller than in its neighboring countries (cluster-robust p-value equal to 0.069; see Appendix Table A3). ${ }^{8}$ Since 89.4 percent of the land outside of Brazil was forested in 2000, this implies that deforestation prior to 2000 was 37 percent higher just inside the Brazilian border relative to on the other side.

\subsection{The Double Reversal of Fortune - Annual forest loss at the border}

We next plot annual deforestation rates on both sides of the border between 2001 and 2018 in Figure 4. The figures show a dramatic difference in deforestation rates in 2001-2005 that come to an abrupt halt in 2006. This is the first reversal we observe. Between 2006 and 2013, deforestation activity is spread smoothly on both sides of the Brazilian border. The change in 2006 comes from decreased deforestation in Brazil, rather than increased deforestation on the other side of the border. Deforestation rates in 2014-2018 return to close to the levels seen in the early-2000's, mostly driven by an increase in deforestation activity in Brazil.

We estimate RD models separately for each year. Figure 5a plots the RD coefficient $\gamma$ in equation $(1)$ - from each year, along with 95 percent confidence intervals, using OLS regressions and a $25 \mathrm{~km}$ bandwidth. We estimate annual deforestation rates of about 0.2 percentage points higher per year on the Brazilian side of the border through 2004. Since deforestation on the other side of the border ranged from 0.05 to 0.07 percent in other Amazonian countries, the estimates imply deforestation rates in Brazil were 3-4 times faster than on the other side of the border.

The dramatic changes we observe at the border correspond to policy changes in Brazil. ${ }^{9}$ First, the precipitous decline in deforestation at the border in the mid-2000s corresponds to a period of environmental policy strengthening in Brazil (Appendix B.1). This followed the appointment in 2003 of Marina Silva as Minister of Environment in the Lula government who was from the Amazon region and had a strong predilection towards conserving the rainforest. Although the comprehensive PPCDAm plan, which she helped craft, was released in 2004, its actions were implemented gradually: most notably with the Law on Public Forest Management and Center for Environmental Monitoring becoming fully operational in 2006. This allowed the satellite-based deforestation detection system (DETER) to become a key tool for targeting law enforcement activities in the Brazilian Amazon, including sending in federal police and troops to arrest illegal loggers and confiscate their machinery (MMA, 2008). Consonant with this, Figure 4 shows that

\footnotetext{
${ }^{8}$ Results vary from 2.8 percentage points to 5.6 percentage points, depending on bandwidth, which we vary from $11 \mathrm{~km}$ to $100 \mathrm{~km}$. Estimates with alternate bandwidths are shown in Appendix Table A3.

${ }^{9}$ Appendix B.2 provides a summary of the main policies in Brazil and neighboring countries.
} 
in 2006 deforestation on the Brazilian side of the border collapses and the discontinuity at the border is eliminated. Taken together, these results point to an important role for Brazilian policy in determining deforestation rates at the border. ${ }^{10}$

Figure 4, however, also shows that the deforestation rate on the Brazilian side of the border resumes growing in 2014. This is the second reversal we observe. Increased deforestation in Brazil is associated with a lowered commitment to environmental regulation. In particular the new Government of Dilma Rousseff introduced a New Forest Code in 2012, which gave an amnesty to those who had engaged in illegal deforestation before 2008. Though contested in the courts (and finally ratified by the Supreme Court in 2018) this introduced considerable uncertainty as to whether illegal deforestation was a crime. Brazilian environmental governance was undermined over the years since 2012 by the growing political power of the agriculture producers, consecutive weak governments and scarce public resources (see Appendix B.1). ${ }^{11}$

Furthermore, 2014 was a particularly turbulent year for the federal government. With elections at the end of the year, the economy started giving signs of a long-lasting economic crisis, and a major corruption scandal erupted involving key politicians from the administration. The upshot of this political and economic crises was that by 2016, the budget of the Brazilian Environmental Agency (IBAMA) was only 57 percent of its budget in 2013 (see Appendix B). The protection environment further deteriorated when Michel Temer, the next president, signed a law that streamlined the titling of occupied public lands, which may have further encouraged land grabs in the Amazon. After three years of political and economic crisis, in 2017 , we see that deforestation was about 0.17 percentage points higher at the Brazilian border (cluster-robust p-value equal to 0.015). ${ }^{12}$

Newly released satellite data therefore allows us to document this widespread reversal across the Brazilian Amazon, and in particular, our border analysis shows that this is a uniquely Brazilian phenomenon. We observe Brazilian deforestation rates (2014-2018) in recent years in Brazil reverting to pre-reform (2001-2005) levels thereby negating eight years of policy reforms (2006-2013) dedicated to slowing the rate of deforestation in the Brazilian Amazon (5a). Given that the Amazon accounts for 40 percent of tropical forests - and Brazil for the bulk of it - this is a troubling finding. Our analysis suggest that the

\footnotetext{
${ }^{10}$ An alternative explanation for the precipitous change we observe in 2006 is a differential change in output prices. To investigate this, we obtained national domestic farmgate prices for soybeans, the main crop in these regions, for both Brazil and Bolivia (the border country closest to the Brazilian agricultural frontier), from the FAO (consistent data on cattle prices are not available). As shown in Appendix Figure A6, farmgate prices move almost directly in parallel in both countries through 2011, and there is no differential break in prices around 2006.

${ }^{11}$ See, e.g., Tollefson (2016); Fearnside (2016); Viola and Franchini (2017); Crouzeilles et al. (2017); Rochedo et al. (2018); Freitas et al. (2018); Soterroni et al. (2018); Tollefson (2018).

${ }^{12}$ Point estimates are statistically significant in all other specifications - using different sets of controls, quadratic polynomial and excluding Mount Roraima (Tables A4), using rectangular kernel, or estimating using Poisson model (Table A5), or using 50 and $100 \mathrm{~km}$ bandwidths (Table A3). The only exception is when using $11 \mathrm{~km}$ bandwidth, OLS estimation and triangular kernel (when cluster-robust p-value is equal to 0.16$)$.
} 
recent reversal is due to political and economic crises colliding with a weakening of forest conservation laws in Brazil (Soares-Filho et al., 2014; Ferreira et al., 2014; Fearnside, 2016; Azevedo et al., 2017; Freitas et al., 2018; Soterroni et al., 2018).

These results are robust to a series of alternative specifications and samples. Our baseline RD specifications use OLS and control for slope and distance to water, use linear polynomials, and are estimated using the entire Brazilian border. Appendix Tables A4 and A5 show that the results are qualitatively similar if we: a) do not include the slope and distance to water controls; b) add additional infrastructure controls; c) estimate using Poisson models; d) use quadratic polynomials; and e) exclude a 220km buffer around the peak of Mount Roraima, a small section of the northern border with Venezuela, which is coincident with a mountain ridge and the only part of the border where there are differences in slope at the border.

We also estimate results restricting the sample to areas around artificial borders, as in Alesina et al. (2011) - i.e., borders arbitrarily drawn by former colonizers which appear as straight lines on a map (Appendix B.3.4). ${ }^{13}$ For these borders, there is no geographic feature at the border - and indeed, usually not even so much as a fence. ${ }^{14}$ These areas correspond to 10 percent of our sample, so our standard errors are correspondingly larger. Nevertheless, we find even larger effects during the period of deforestation slowdown, as shown in Figure A1 (see Appendix Table A5). We do not observe a statistically significant ramp up post-2014 in deforestation in this subsample, though we cannot reject statistically the effects of the magnitude we see in our full analysis sample.

\subsection{Are these differences about Brazil?}

An important question is whether the differences we observe at the border reflect differences in the policy environment within Brazil, as opposed to changes happening on the other side of the border. Examining Figure 4 suggests prima facie that they are about changes in Brazil - the deforestation rates on the non-Brazil side of the border are remarkably similar from year to year, whereas the two reversals we document are all due to changes (first decreases, then increases) on the Brazilian side of the border. The only time we see major changes outside of Brazil is 2016, when deforestation outside Brazil appears to increase - but deforestation increases even more on the Brazilian side of the border, as shown in the discontinuity estimates.

Nevertheless, to explore this issue in more detail, we further investigate heterogeneity in effects by land type within Brazil, and heterogeneity based on what country is on the

\footnotetext{
${ }^{13}$ We map the segments of artificial border in Figure A7b in the appendix.

${ }^{14}$ In fact, in one famous incident, President-elect Cardoso of Brazil went hiking near the border in 1994, and accidentally ended up in Bolivia - and was there for over an hour before anyone realized he was in the wrong country (Cardoso and Winter, 2006, pp. 218-219).
} 
other side of the border.

\subsubsection{Heterogeneity by land classification within Brazil}

We begin by examining heterogeneity in effects based on the land use classification of different areas within Brazil. Land in the Brazilian Amazon is divided into areas that are protected for conservation and other reasons (e.g., national parks), areas which are untitled and unclaimed and areas which are under private ownership. Since 1998, harming native vegetation in Protected Areas (PAs) was a felony subject to potentially harsh legal procedures and punishments - including possible jail time. This category of land thus faced the highest level of de jure sanction throughout the 2000-2018 period. In contrast, PPCDAm made several changes that increased enforcement outside PAs.

Most notably, until 2005, deforesting untitled, or unclaimed land, outside PAs was just an infraction, punishable at most with fines, and individuals caught harming native vegetation or extracting resources in these lands would not even have their equipment seized. PPCDAm, which was fully implemented in 2006 when real-time satellite data became available for enforcement, made deforestation of unclaimed land a felony punishable with jail time, as in PAs, and legislated that equipment (i.e., trucks and chainsaws) of violators could be seized and confiscated.

Similarly until 2005, private properties outside PAs were required to set aside at least 35 percent of their area as native vegetation - i.e., it was illegal to deforest more than 65 percent of the private property area. Non-compliance with this threshold, however, was just an infraction. Starting in 2005, PPCDAm both increased the required set-aside area of private properties from 35 to 80 percent $^{15}$ and conditioned access to agricultural credit lines from public banks on environmental compliance (Assunção et al., 2013).

To explore whether differences in de jure enforcement regimes translated into differences in de facto deforestation at the border, we re-estimate equation (1) separately for each of these three classes of land. Figure $5 \mathrm{~b}$ presents the results, where every point is an estimated RD coefficient (i.e., $\gamma$ from (1)) from a separate Poisson regression using 25km bandwidths.

We see that when the national border abuts Brazilian PAs we observe less deforestation on the Brazilian side consistent with these areas enjoying greater de jure protection throughout our whole period. In strict contrast, for unclaimed lands we observe more deforestation on the Brazilian side up until 2005, but this discontinuity is eliminated from 2006 when PPCDAm comes into full force. For private lands, while there is a dramatic fall in the difference in deforestation rates in 2006, it is not eliminated entirely, consistent with the fact that some deforestation was still allowed in these areas. These results con-

\footnotetext{
${ }^{15}$ Pre-2005 infringements were not prosecuted but landowners were liable for any deforestation above the 20 percent requirement from 2005 onward.
} 
firm that - even in these remote areas very close to the international border - differences in deforestation map to changes in land use regulations within Brazil.

\subsubsection{Heterogeneity by bordering country}

The border discontinuity our identification strategy exploits captures the net policy difference at the border. Although Figure 4 suggests that most of the effects we document come from decreased, and subsequently increased, deforestation on the Brazilian side of the border, our estimates could be influenced by changes in the environmental policies in other countries in the Amazon region. We did not identify any crucial land use and deforestation policy changes in neighboring countries to Brazil that could undermine our interpretation of the estimates. ${ }^{16}$

Nonetheless, we next investigate whether the effects we see are homogeneous across all country border segments by re-estimating equation (1) separately for the border segment with each country. Figure A3 presents the results, analogous to Figure 5b. Our estimated effects are almost identical when comparing the Brazilian border with Bolivia with the Brazilian border with Peru, the two countries where the so-called "Arc of Deforestation"i.e., where deforestation rates are highest - intersects the international border.

We find no statistically meaningful differential deforestation in the whole period for the more remote areas bordering Colombia, Venezuela, Guyana, Suriname, and French Guiana (see Figure A3b), though the point estimates suggest higher deforestation in Brazil along the Venezuelan border and the Northern border with Guyana, Suriname and French Guiana during the early part of our sample. It is important to note, however, that there is very little deforestation on either side of the border in these very remote locations. For example, while the annual deforestation rate in Brazil in 2001 near the Bolivian border is 1.14 percent, it ranges between only 0.02 and 0.05 percent on all other country borders. Thus, in the segment of the international border where deforestation is substantial, the fact that we find nearly identical effects of being in Brazil suggests that the effects are about Brazilian policy, rather than policies in the countries on the other side of the border.

\subsection{Heterogeneity by distance from markets and enforcement}

To the extent the effects we document are driven by the interplay between demand for deforestation and enforcement, we should expect to find heterogeneity in effects along both these dimensions. We therefore investigate heterogeneity in effects based on markets access and enforcement. First, we look at heterogeneous effects by distance to roads as a proxy for market access and transportation cost. We estimate equation (1) separately for the pixels in each tercile of the distribution of distance to roads. The solid line in

\footnotetext{
${ }^{16}$ Appendix B.2 provides a summary of the main policies in Brazil and neighboring countries.
} 
Figure A4a shows the estimates for pixels within $15 \mathrm{~km}$ to roads (the $33 \mathrm{rd}$ percentile), the dashed line shows pixels between 15 and $50 \mathrm{~km}$ to roads (the 66 th percentile) and the red line shows pixels further than $50 \mathrm{~km}$ from roads. We see that all differential deforestation comes from the third of pixels closer to roads. We find no clear pattern of differential deforestation rates in pixels more than $50 \mathrm{~km}$ away from roads.

Second, we use distance to towns or villages to capture proximity to local markets. Similar to heterogeneity by roads, Figure A4b shows larger effects in pixels closer to villages. This is consistent with changes in deforestation being more pronounced where pressures for extraction are greatest.

Last, we look at heterogeneous effects by distance to the 10 enforcement bases from the Brazilian Environmental Agency (IBAMA). Given the size of the Amazon, we see that one third of pixels around the national border are within $565 \mathrm{~km}$ from an enforcement base, and one third of pixels are more than $880 \mathrm{~km}$ away from an enforcement bases. Figure A5 shows the estimates for pixels within each of tercile of distance to enforcement. The results in Figure A5 suggest that the double reversal of fortune happened in areas closer to IBAMA enforcement bases. The solid line shows that PPCDAm's largest reduction in annual deforestation rate happened until 2009 in the areas closest to enforcement within $565 \mathrm{~km}$. Likewise, the dark lines show that the effect of Brazilian deforestation policy started to weaken around 2013 in areas closer to enforcement, with deforestation rates being higher on the Brazilian side since then. The red dashed line shows smaller annual deforestation rates on the Brazilian side of the border in more remote pixels, further than $880 \mathrm{~km}$ away from enforcement bases, in the whole period.

In sum, in the first reversal Brazilian effort to cope with illegal deforestation was effective in reducing forest loss exactly in those areas closer to economic and market pressure and to law enforcement bases. However, as the policy position towards environmental regulation shifted in Brazil it was precisely these areas that experienced accelerated deforestation during the second reversal. This analysis thus underlines the extent to which rates of deforestation in Brazil depended on enforcement of national policies.

\section{Conclusion}

By using fine grained satellite data we are able to test whether Brazilian conservation policies had any bite at the national border. This is an interesting exercise as there has been considerable skepticism regarding the ability of the state to exercise control over global ecosystems. In effect, the ability of the state to conserve ecosystems may fall as locations become remote, which opens up opportunities for those who want to illegally extract resources. Given that rapid environmental degradation in developing countries is being driven by illegal extraction it is important to empirically assess whether or not the 
state has the power to conserve natural resources in these remote locations.

This is the contribution of this paper. We observe sharp discontinuities in forest loss at the border, a diminution in these as Brazil implemented policies to detect and penalize illegal logging, but then document a second reversal once Brazilian enforcement slackens. Our results therefore demonstrate the power of the state to determine whether wilderness ecosystems are conserved or exploited. Moreover, the pattern of diminution within Brazil, where post-2005 deforestation rates fall mainly in non-protected areas but increase amid legal and political uncertainty post-2013, again points to the influence of national policies on conservation.

This finding has implications beyond Brazil. The future path of the earth's climate will, to some significant extent, be determined by whether vast wilderness ecosystems like the Amazon can be kept intact. The fact that Brazil moves from having almost the highest rate of deforestation in 2001 to having the lowest rate less than a decade later is testament to how conservation policy can be turned around. Part of this turnaround was achieved by the Brazilian state coupling better monitoring (through use of satellite data) with more stringent enforcement (through the use of federal police). The growing rise in deforestation rate experienced by Brazil from 2014 onwards, however, points to how quickly such policies can unravel when political backing for national and international conservation efforts evaporates. Indeed, Brazil has moved from congruence to dissonance as regards to international efforts to slow climate change by slowing tropical deforestation.

The success of wilderness conservation, therefore, ultimately depends on the policy choices of national governments. Information on illegal logging, for example, is regularly available to any government at a 30-meter resolution (Hansen et al., 2013). Whether or not governments act on this information is another matter and depends largely on the political willingness to do so. Nevertheless, the remarkable reversal we document in Brazil suggests that it is possible to reduce the gap between de jure and de facto conservation policy, even in wilderness areas in developing countries. This is an important proof of concept for other countries considering strengthening their conservation efforts.

The transitory nature of the gains in Brazil, however, underlie how difficult it is to maintain a pro-conservation equilibrium when there are short term economic gains to be had from exploiting natural resources. More research is needed to understand how the incentives of government's intent on promoting growth and development can be brought in line with longer-term conservation objectives. 


\section{References}

Adman, R. (2014). Reelection Incentives, Blacklisting and Deforestation in the Brazilian Amazon.

Alesina, A., W. Easterly, and J. Matuszeski (2011). Artificial States. Journal of the European Economic Association 9(2), 246-277.

Anderson, L. O., S. De Martino, T. Harding, K. Kuralbayeva, and A. Lima (2016). The Effects of Land Use Regulation on Deforestation: Evidence from the Brazilian Amazon. OxCarre Working Paper No. 172.

Asher, S., T. Garg, and P. Novosad (2017). The Ecological Footprint of Transportation Infrastructure.

Assunção, J., C. Gandour, and R. Rocha (2013). DETERring Deforestation in the Brazilian Amazon: Environmental Monitoring and Law Enforcement. Technical report, Climate Policy Initiative.

Assunção, J., C. Gandour, R. Rocha, and R. Rocha (2013). Does Credit Affect Deforestation? Evidence from a Rural Credit Policy in the Brazilian Amazon. Technical report, Climate Policy Initiative.

Assunção, J., C. C. Gandour, and R. Rocha (2015). Deforestation Slowdown in the Legal Amazon: Prices or Policies? Environment and Development Economics 20(6), 697-722.

Azevedo, A. A., R. Rajão, M. A. Costa, M. C. Stabile, M. N. Macedo, T. N. dos Reis, A. Alencar, B. S. Soares-Filho, and R. Pacheco (2017). Limits of Brazil's Forest Code as a Means to End Illegal Deforestation. Proceedings of the National Academy of Sciences $114(29), 7653-7658$.

Black, S. E. (1999). Do Better Schools Matter? Parental Valuation of Elementary Education. The Quarterly Journal of Economics 114(2), 577-599.

Calonico, S., M. D. Cattaneo, and R. Titiunik (2014). Robust Nonparametric Confidence Intervals for Regression-Discontinuity Designs. Econometrica 82(6), 2295-2326.

Cardoso, F. H. and B. Winter (2006). The Accidental President of Brazil: a Memoir. New York, PublicAffairs.

CGU, C. (2016). Relatório de Avaliação da Execução de Programas de Governo N. 69: Ações Relativas á Fiscalização Ambiental sob Responsabilidade do IBAMA. Brasília: $C G U$.

Chimeli, A. B. and R. R. Soares (2017). The Use of Violence in Illegal Markets: Evidence from Mahogany Trade in the Brazilian Amazon. American Economic Journal: Applied Economics 9(4), 30-57.

Conley, T. G. (1999). GMM Estimation with Cross Sectional Dependence. Journal of Econometrics 92(1), 1-45.

Crouzeilles, R., R. Feltran-Barbieri, M. S. Ferreira, and B. B. Strassburg (2017). Hard Times for the Brazilian Environment. Nature Ecology \&6 Evolution 1(9), 1213. 
D'Anville, J.-B. B. (1779, Aout 10). Mémoire Sur un Accroissement Considérable de Connoissances Locales en ce qui Intéresse l'Amérique Méridionale. n. 539, 11p. In: Furtado (2012). Oraculos da Geografia Iluminista: Dom Luís da Cunha e Jean-Baptiste Bourguignon d'Anville na Construção da Cartografia do Brasil. Editora UFMG, 2012.

Fearnside, P. M. (2012). Brazil's Amazon Forest in Mitigating Global Warming: Unresolved Controversies. Climate Policy 12(1), 70-81.

Fearnside, P. M. (2016). Brazilian Politics Threaten Environmental Policies. Science 353(6301), 746-748.

Ferreira, J., L. E. O. C. Aragão, J. Barlow, P. Barreto, E. Berenguer, M. Bustamante, T. A. Gardner, A. C. Lees, A. Lima, J. Louzada, R. Pardini, L. Parry, C. A. Peres, P. S. Pompeu, M. Tabarelli, and J. Zuanon (2014). Brazil's Environmental Leadership at Risk. Science 346(6210), 706-707.

Freitas, F. L., G. Sparovek, G. Berndes, U. M. Persson, O. Englund, A. Barretto, and U. Mörtberg (2018). Potential Increase of Legal Deforestation in Brazilian Amazon After Forest Act Revision. Nature Sustainability 1(11), 670.

Furtado, J. F. (2012). Oraculos da Geografia Iluminista: Dom Luís da Cunha e JeanBaptiste Bourguignon d'Anville na Construção da Cartografia do Brasil. Editora UFMG.

Gelman, A. and G. Imbens (2019). Why High-Order Polynomials Should Not Be Used in Regression Discontinuity Designs. Journal of Business 85 Economic Statistics 37(3), $447-456$.

Godar, J., T. A. Gardner, E. J. Tizado, and P. Pacheco (2014). Actor-Specific Contributions to the Deforestation Slowdown in the Brazilian Amazon. Proceedings of the National Academy of Sciences 111 (43), 15591-15596.

Hansen, M. C., P. V. Potapov, R. Moore, M. Hancher, S. Turubanova, A. Tyukavina, D. Thau, S. Stehman, S. Goetz, T. Loveland, et al. (2013). High-Resolution Global Maps of 21st-Century Forest Cover Change (v1.6). Science 342(6160), 50-853.

Holmes, T. J. (1998). The Effect of State Policies on the Location of Manufacturing: Evidence from State Borders. Journal of Political Economy 106(4), 667-705.

Imbens, G. and K. Kalyanaraman (2012). Optimal Bandwidth Choice for the Regression Discontinuity Estimator. The Review of Economic Studies 79(3), 933-959.

IPBES (2018). Plenary of the Intergovernmental Science-Policy Platform on Biodiversity and Ecosystem Services, 6th Session.

Michalopoulos, S. and E. Papaioannou (2014). National Institutions and Subnational Development in Africa. The Quarterly Journal of Economics 129(1), 151-213.

MMA, M. d. M. A. (2008). Plano de Ação para Prevenção e Controle do Desmatamento na Amazônia Legal (PPCDAm). Documento de Avaliação 2004-200\%. 
MMA, M. d. M. A. (2013). Plano de Ação para Prevenção e Controle do Desmatamento na Amazônia Legal (PPCDAm) 3a Fase (2012-2015) pelo uso sustentável e conservação da Floresta. Brasília.

Nepstad, D., B. S. Soares-Filho, F. Merry, A. Lima, P. Moutinho, J. Carter, M. Bowman, A. Cattaneo, H. Rodrigues, S. Schwartzman, et al. (2009). The End of Deforestation in the Brazilian Amazon. Science 326 (5958), 1350-1351.

Nolte, C., A. Agrawal, K. M. Silvius, and B. S. Soares-Filho (2013). Governance Regime and Location Influence Avoided Deforestation Success of Protected Areas in the Brazilian Amazon. Proceedings of the National Academy of Sciences 110(13), 4956-4961.

Pfaff, A. S. (1999). What Drives Deforestation in the Brazilian Amazon? Evidence from Satellite and Socioeconomic Data. Journal of Environmental Economics and Management 37(1), 26-43.

Pinkovskiy, M. L. (2017). Growth Discontinuities at Borders. Journal of Economic Growth 22(2), 145-192.

Rochedo, P. R., B. Soares-Filho, R. Schaeffer, E. Viola, A. Szklo, A. F. Lucena, A. Koberle, J. L. Davis, R. Rajão, and R. Rathmann (2018). The Threat of Political Bargaining to Climate Mitigation in Brazil. Nature Climate Change 8(8), 695.

Soares-Filho, B., R. Rajão, M. Macedo, A. Carneiro, W. Costa, M. Coe, H. Rodrigues, and A. Alencar (2014). Cracking Brazil's Forest Code. Science 344(6182), 363-364.

Soterroni, A. C., A. Mosnier, A. X. Carvalho, G. Câmara, M. Obersteiner, P. R. Andrade, R. C. Souza, R. Brock, J. Pirker, F. Kraxner, et al. (2018). Future Environmental and Agricultural Impacts of Brazil's Forest Code. Environmental Research Letters 13(7), 074021.

Souza-Rodrigues, E. (2018). Deforestation in the Amazon: A Unified Framework for Estimation and Policy Analysis. The Review of Economic Studies.

Tollefson, J. (2016). Political Upheaval Threatens Brazil's Environmental Protections. Nature News 539(7628), 147-148.

Tollefson, J. (2018). Brazil's Lawmakers Renew Push to Weaken Environmental Rules. Nature $557(7706), 17$.

Turner, M. A., A. Haughwout, and W. van der Klaauw (2014). Land Use Regulation and Welfare. Econometrica 82(4), 1341-1403.

Viola, E. and M. Franchini (2017). Brazil and Climate Change: Beyond the Amazon. New York, Routledge. 


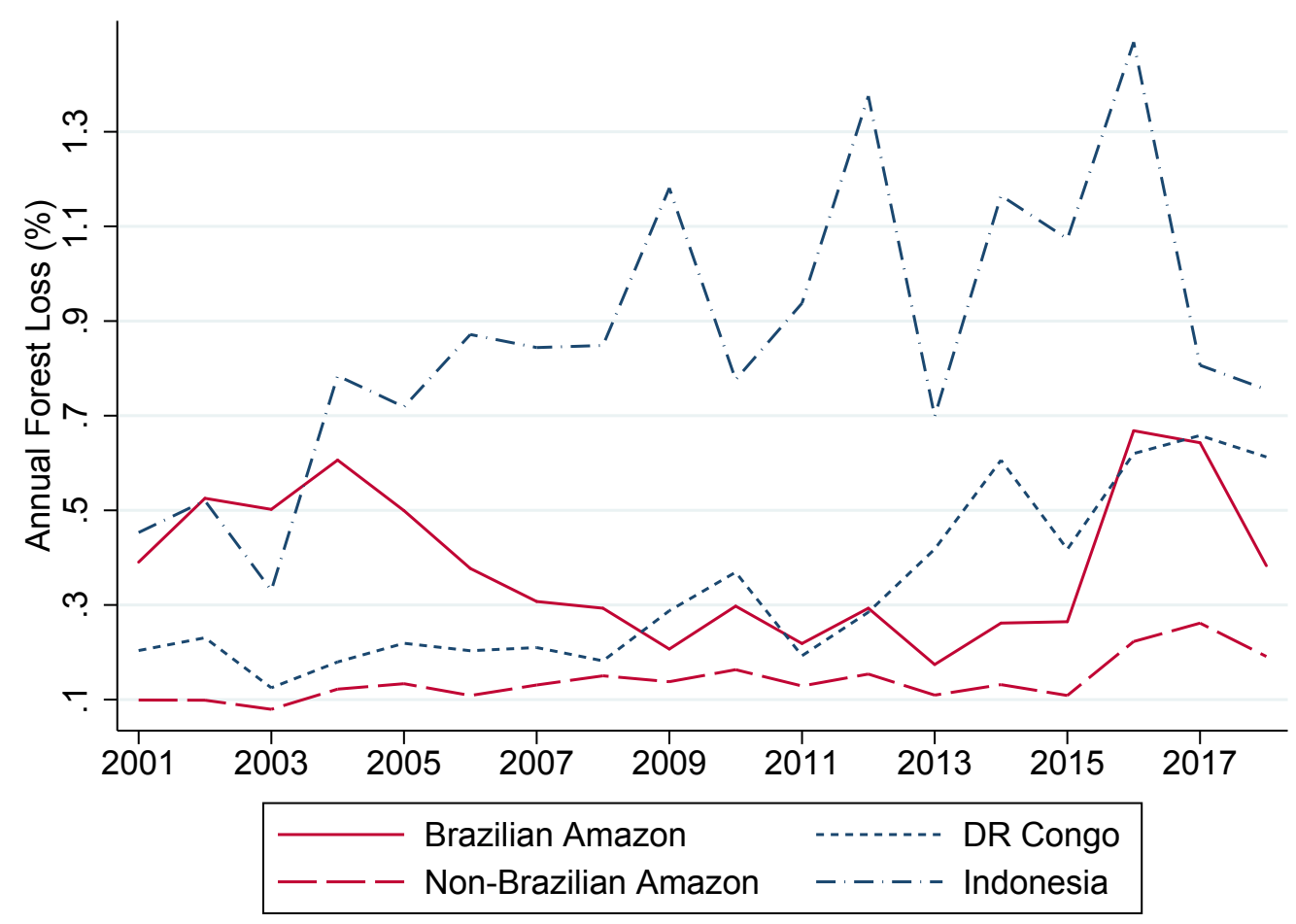

Figure 1: Forest Change in the Amazon, DR Congo and Indonesia, 2001-2018

This figure shows the annual forest loss in the Brazilian and non-Brazilian Amazon, in the Democratic Republic of the Congo and Indonesia, as calculated by the authors using data from (Hansen et al., 2013). The solid red line shows that the Brazilian Amazon was the only region to go thorough almost a decade of declining deforestation rate. Forest loss is measured as the share of forest cover in each country that was lost in each year. 


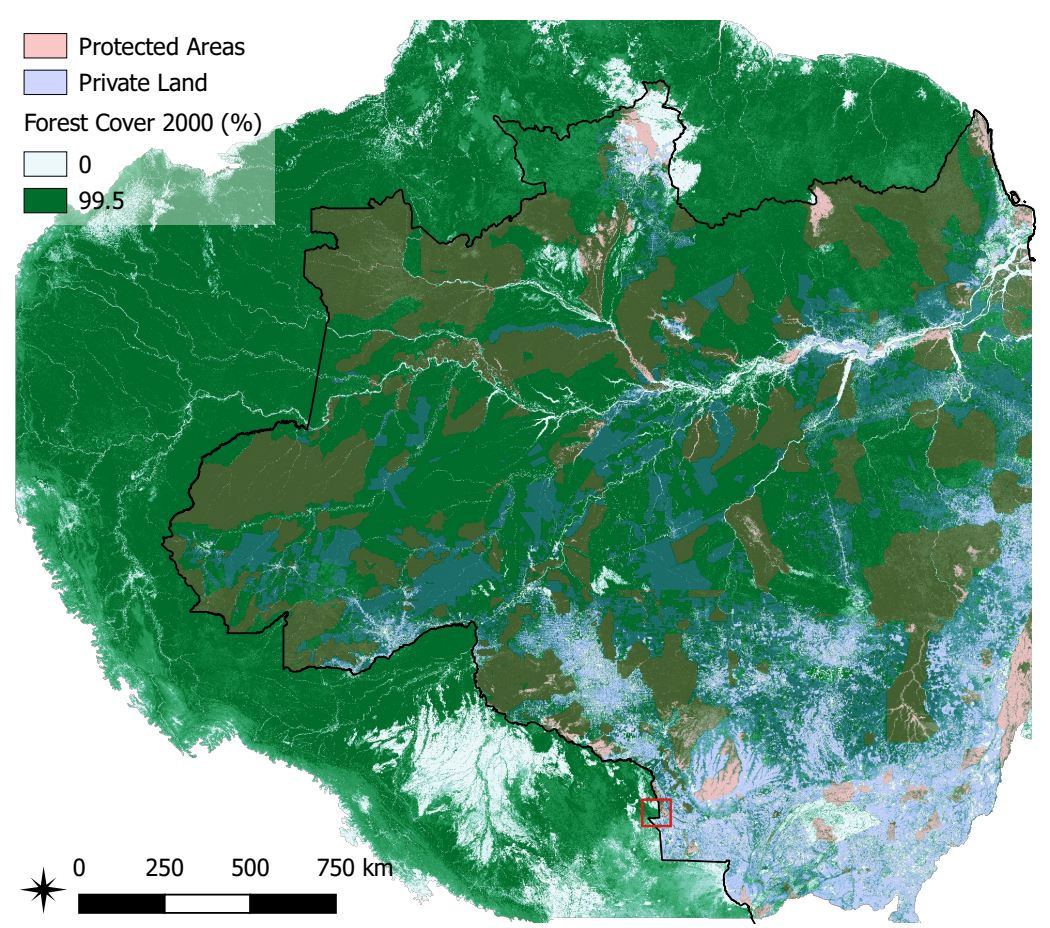

(a) Overview

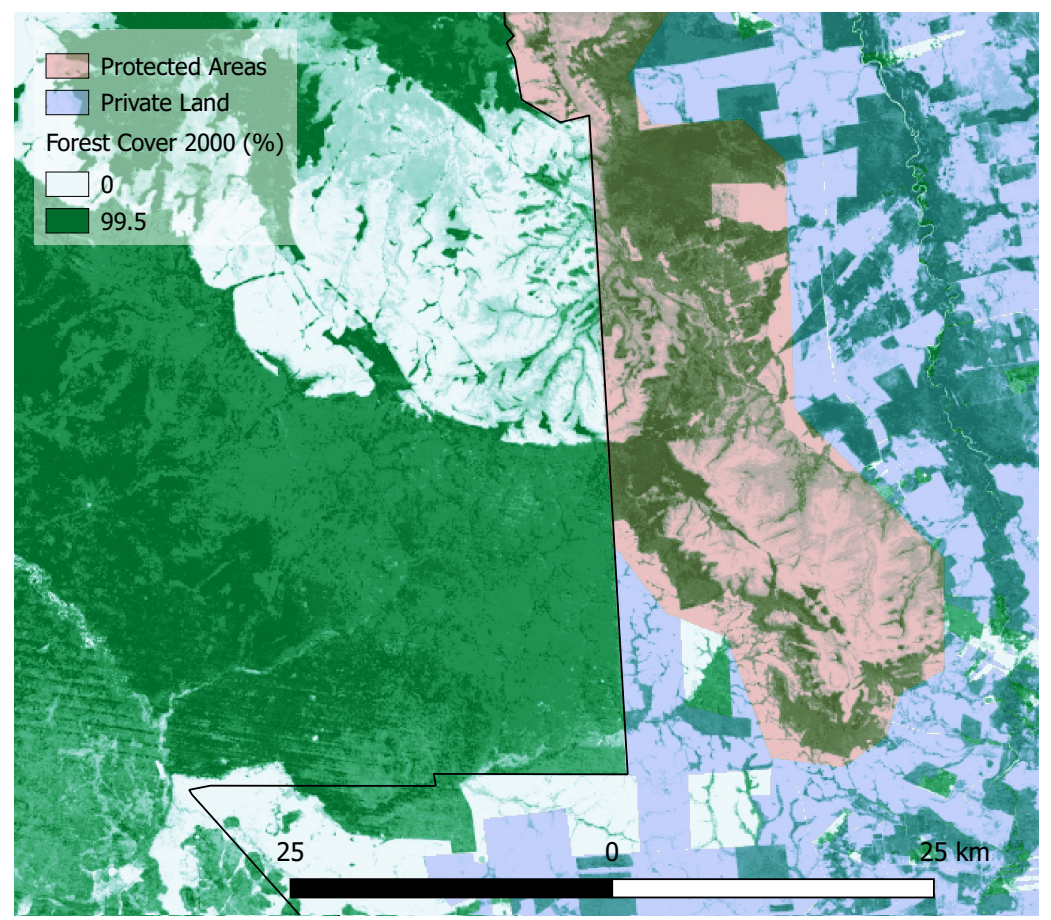

(b) Example of area of border with Bolivia

Figure 2: Satellite Image of a Border Segment (Percentage of Forest Cover in 2000)

This figure shows the percentage of forest cover in 2000 by 120 -meter pixels, as calculated by the authors using data from (Hansen et al., 2013). The top panel (a) shows the Amazon, and the bottom panel (b) shows a zoom in a segment of the border between Brazil and the Southern border with Bolivia (marked with a red square in the top panel). The black solid line is the Brazilian border. Forest cover in shades of green (white are deforested pixels). Red shades mark Protected Areas as of 2004. Blue shades mark private non-protected land. 


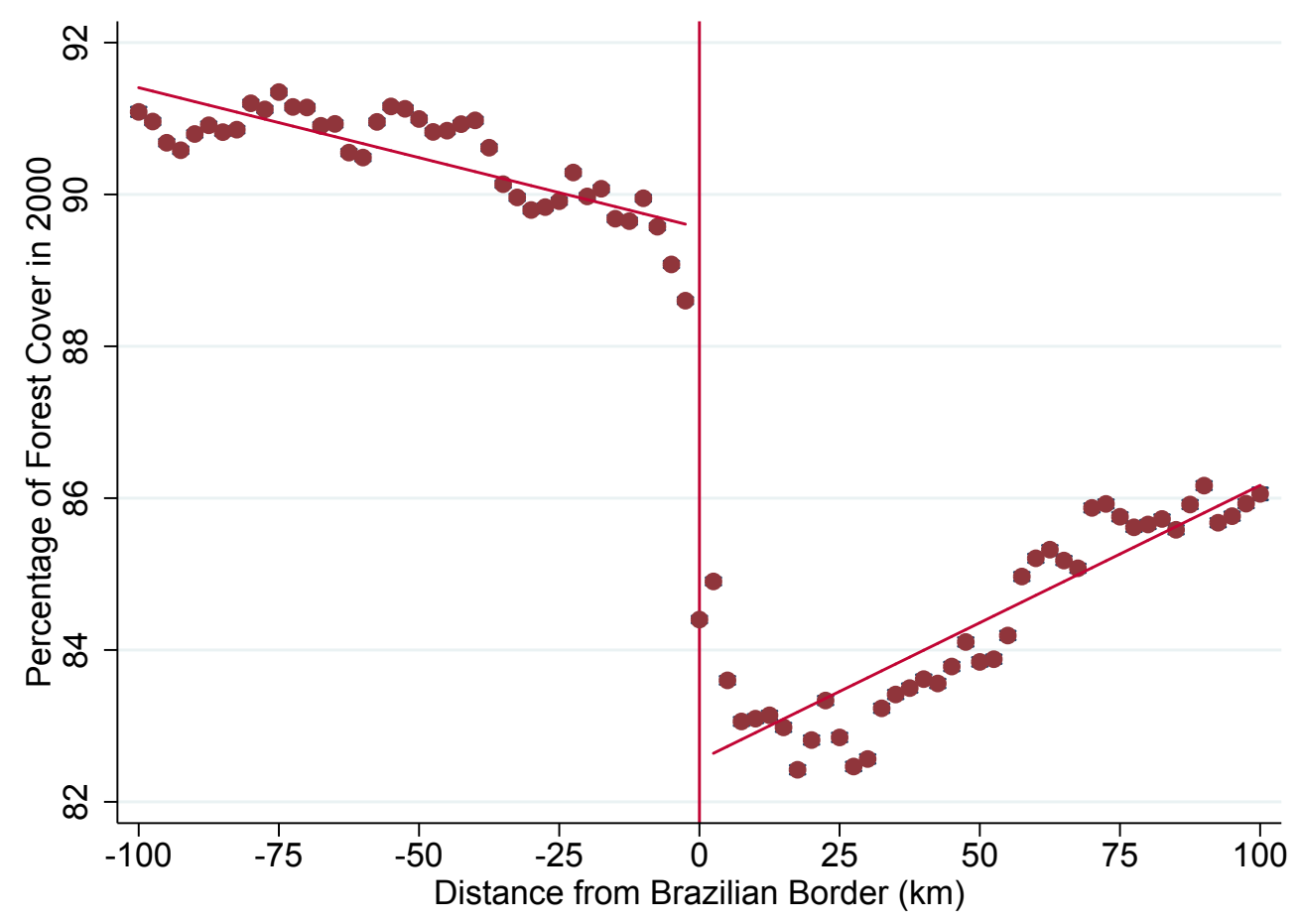

Figure 3: Average Forest Cover in 2000 by Distance from Brazilian Border

This figure shows the average forest cover in 2000 by 80 equal-sized bins of distances from the Brazilian border, up to 100 kilometers away from the border. Positive distance represents Brazilian land, while negative distance represents non-Brazilian land. The graph shows the abrupt reduction in forest cover at the Brazilian border. The red line shows the linear function of distance weighted by the number of observations in each bin. 

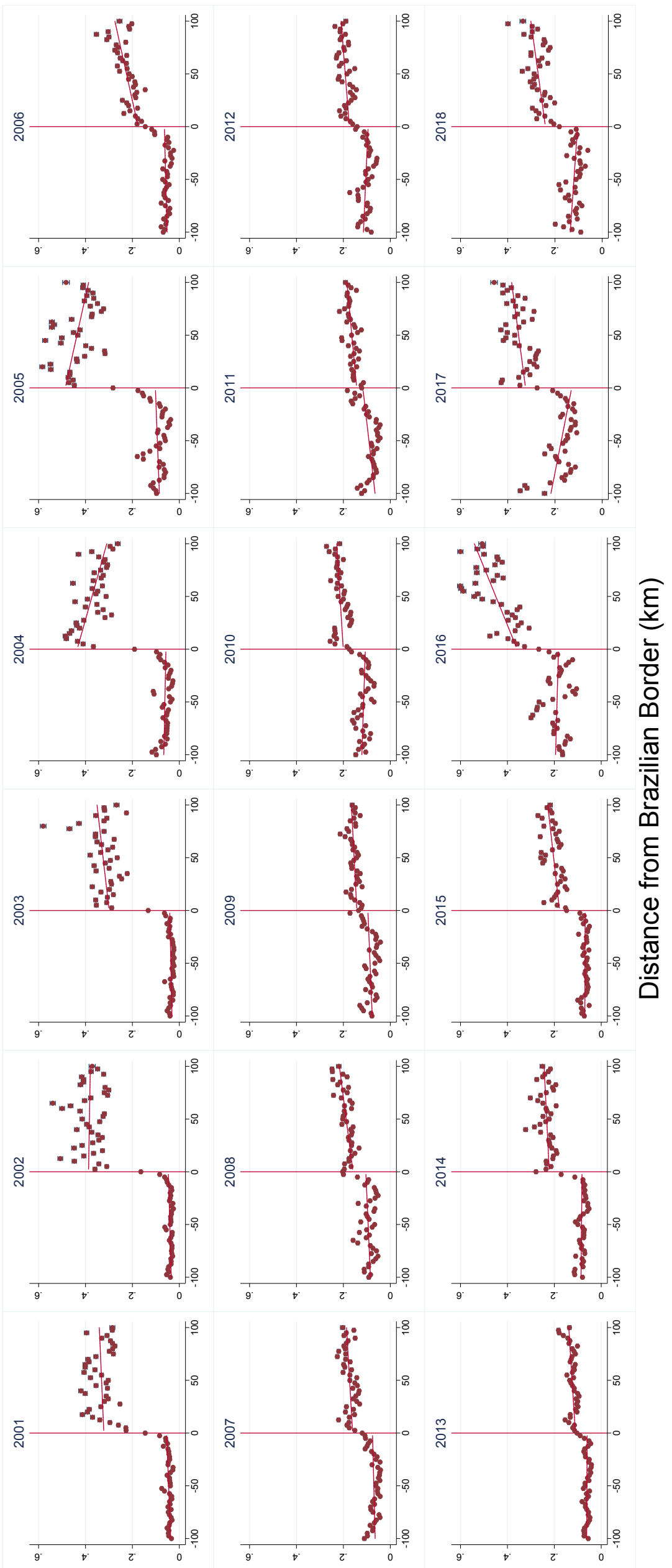

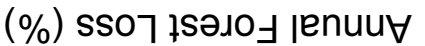

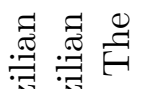
ติ山 웜 : जू 范 卷 贾 总 究劳

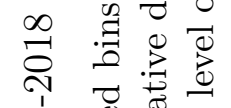

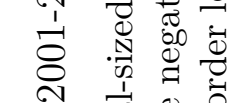
ह ซึ छ্ర

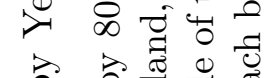
s.

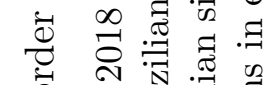
苟 ๑ ఫ त क्त की

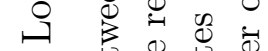
苟 范要

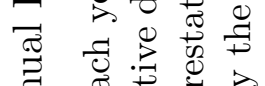

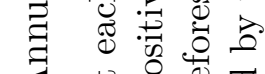

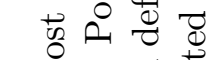
\& 苛 ४ भi

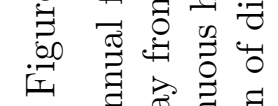
สี 证 离 焉: త్ 舫焉 क ङ

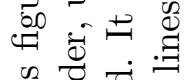

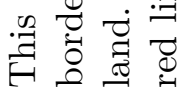




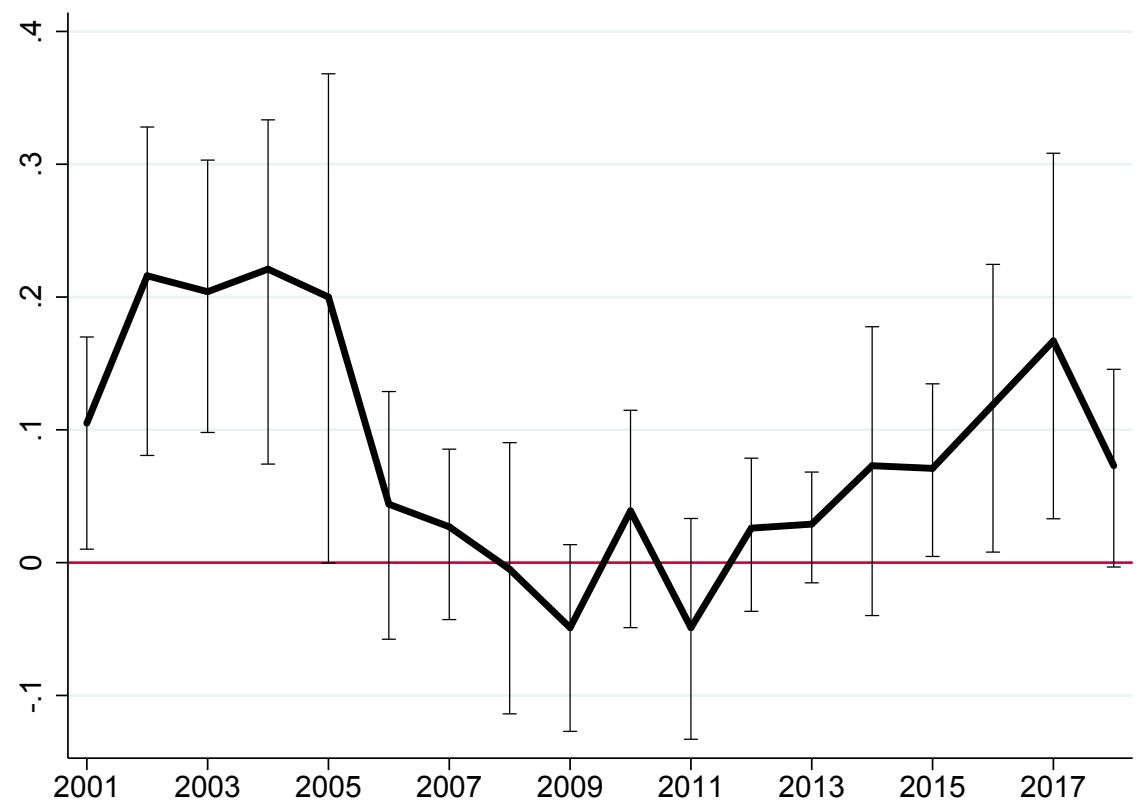

(a) Overall Effects (OLS model)

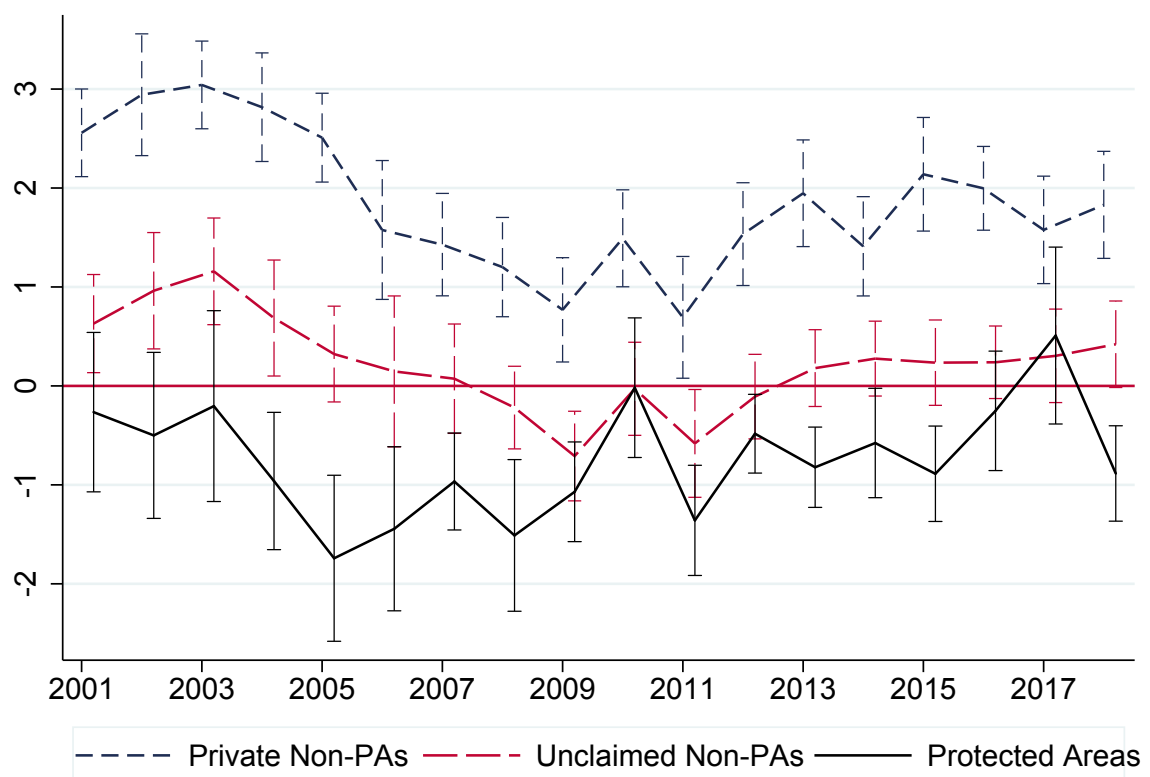

(b) Heterogeneous Effects by Land Type (Poisson model)

Figure 5: Regression Discontinuity Coefficients by Year

This figure shows the regression discontinuity coefficients of the Brazilian effect, $\gamma$, on the percentage of annual forest loss by year, from equation (1) with linear running variables and 25 $\mathrm{km}$ bandwidth. The top panel (a) shows the overall effects estimated using the whole Brazilian border trough OLS regressions (presented in column 1 Table $A 3$ in Appendix). The vertical bars represent 95 percent confidence intervals. The bottom panel (b) shows the heterogeneous effects by land type estimated using a Poisson model (presented in Table A6 in Appendix). These estimates can be interpreted as a relative increase in annual deforestation rate on the Brazilian side of the border. 


\section{Appendix (for online publication only)}

\section{A Appendix Figures and Tables}

In this section we present the tables with summary statistics of the data and the estimates presented in Figures 5 and A1, as well as all robustness exercises mentioned in the paper. We also present the main robustness tests graphically. 


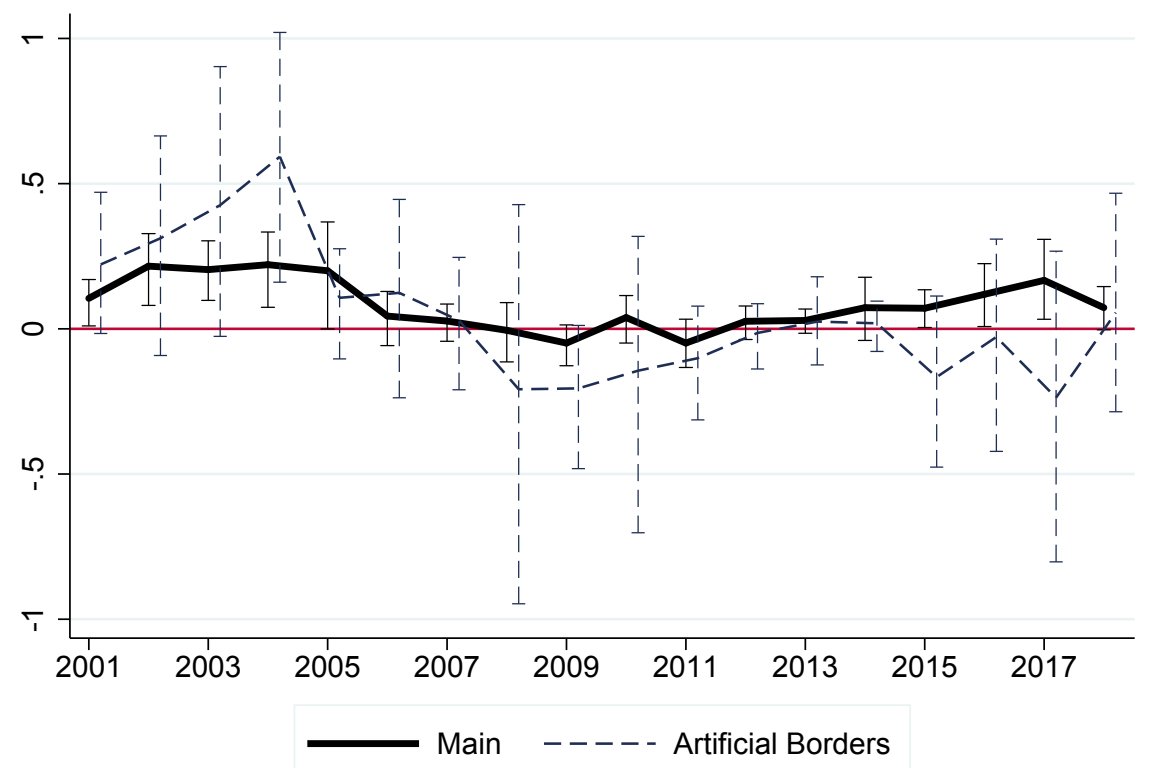

(a) OLS model

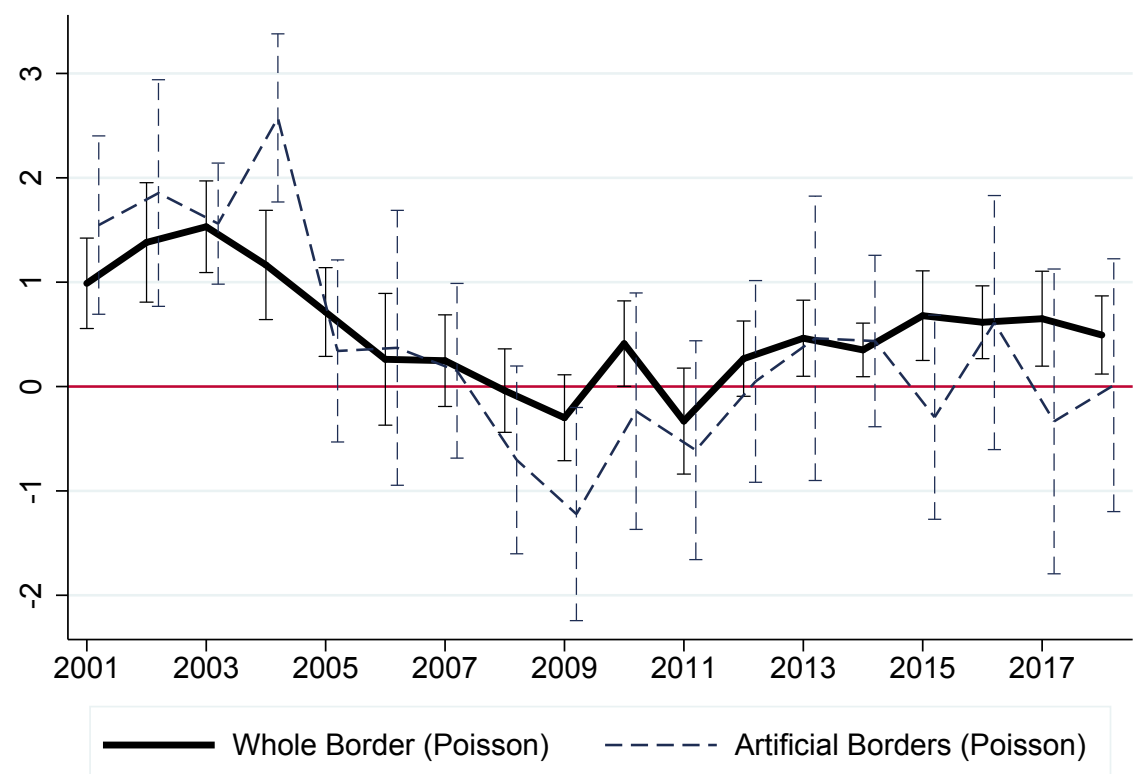

(b) Poisson model

Figure A1: Artificial Border Segments

This figure shows the results when one restricts attention to artificial borders. It plots the regression discontinuity coefficients of the Brazilian effect, $\gamma$, on the percentage of annual forest loss by year, from equation (1) estimated with linear running variables and $25 \mathrm{~km}$ bandwidth. Solid lines shows effects estimated with the whole border, and dashed lines shows effects estimated restricting the sample to pixels around artificial borders. The top panel (a) estimates the model using OLS regressions - presented in column 1 Table $A 3$ and column 1 Table $A 5$ - and the bottom panel (b) estimates using a Poisson model - presented in columns 3 and 4 Table $A 5$. The vertical bars represent 95 percent confidence intervals. 

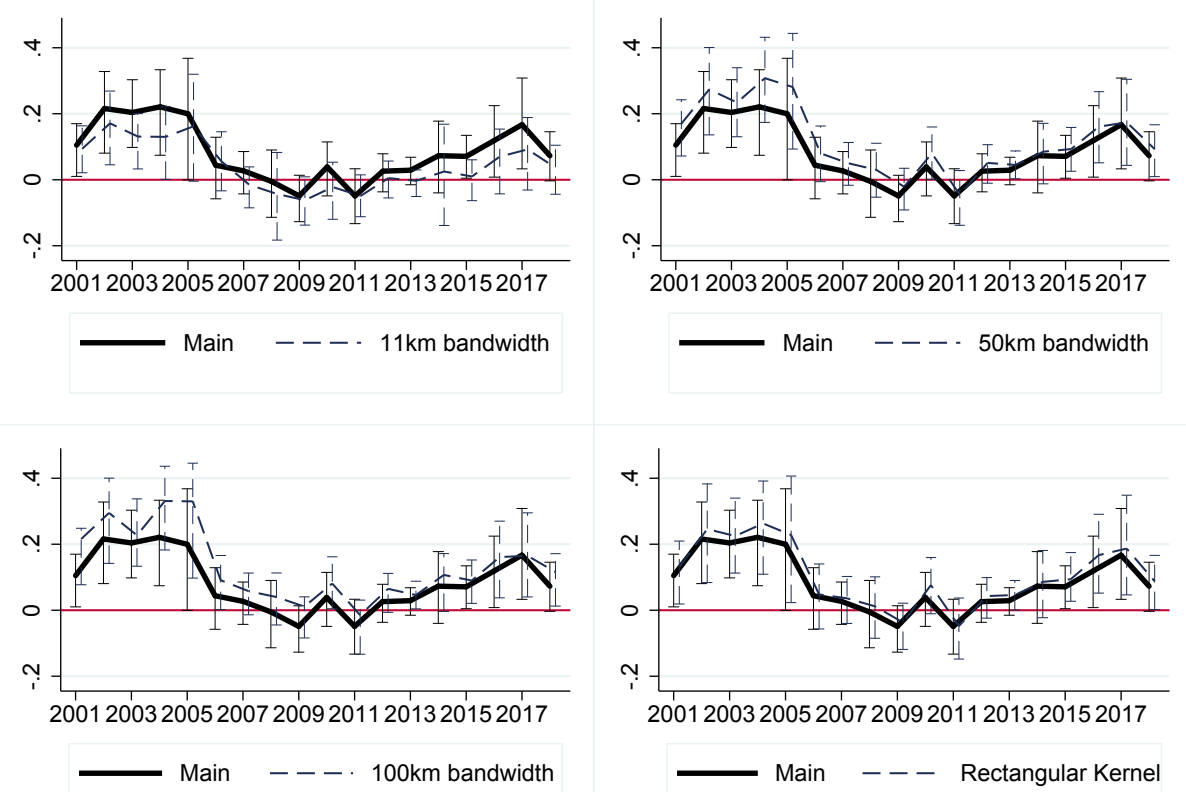

(a) Different Bandwidth
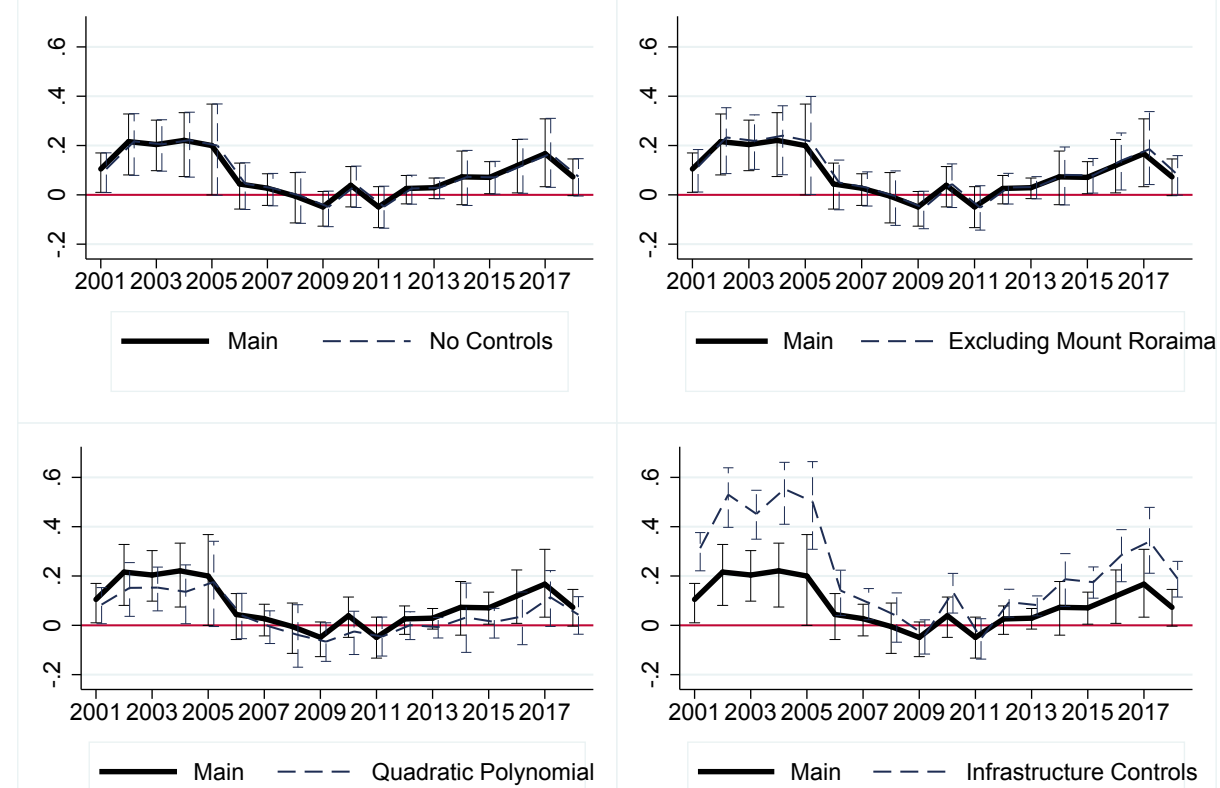

(b) Robustness

Figure A2: Regression Discontinuity Coefficients by Year

This figure shows the results for different bandwidths and robustness specifications. It plots the regression discontinuity coefficients of the Brazilian effect, $\gamma$, on the percentage of annual forest loss by year, from equation (1). The solid lines use a $25 \mathrm{~km}$ bandwidth - our main specification - presented in column 1 Table $A 3$. The upper panel shows specifications with linear running variables and different bandwidths (dashed lines) from $11 \mathrm{~km}$ to $100 \mathrm{~km}$ as indicated in each panel - presented in Table $A 3$. The bottom panel shows different specifications (dashed lines) with linear running variables and a $25 \mathrm{~km}$ bandwidth - presented in Table $A 4$. The vertical bars represent 95 percent confidence intervals. 


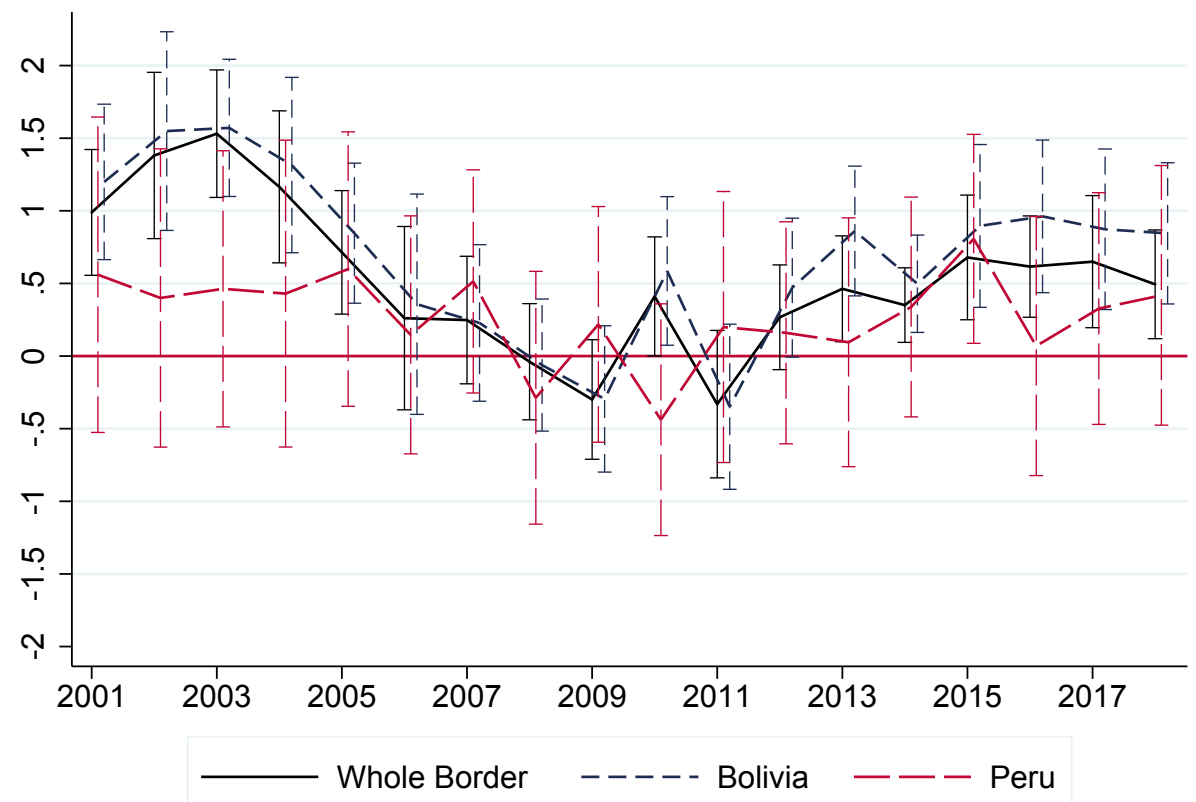

(a) Bolivia and Peru

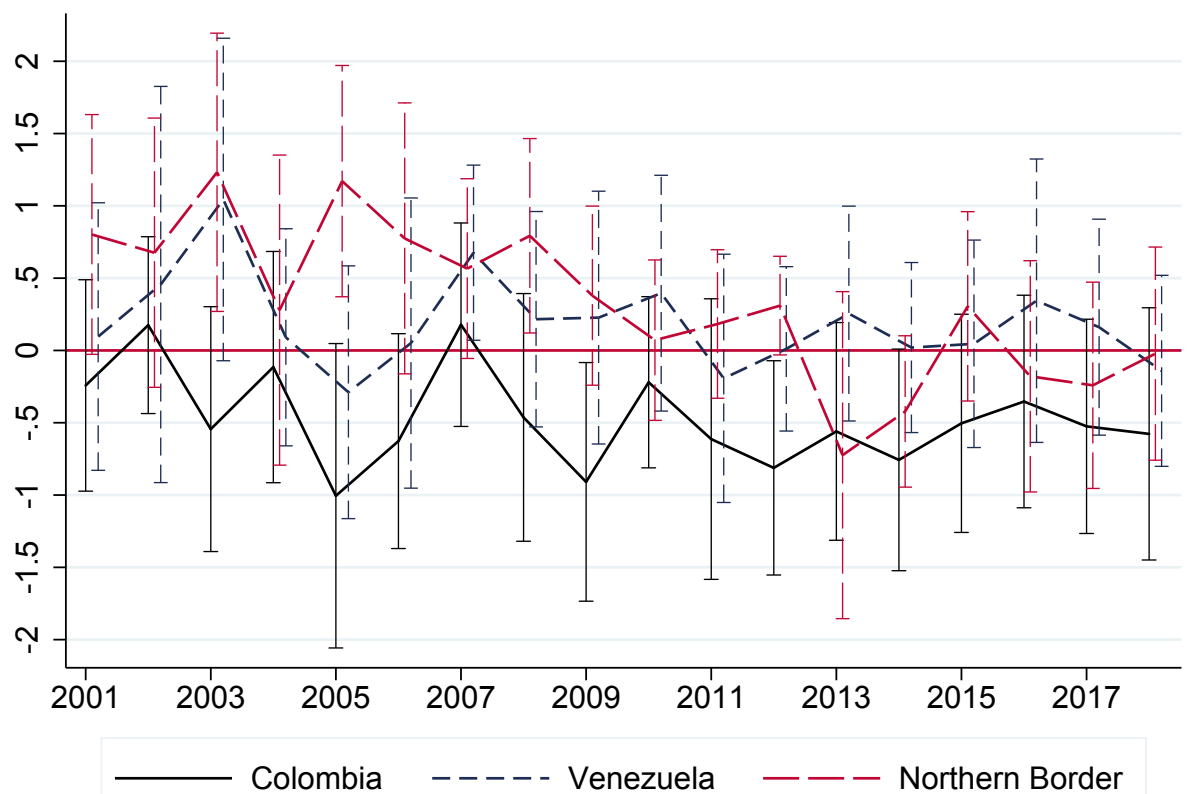

(b) Colombia, Venezuela and Guyana, Suriname and French Guiana

Figure A3: Regression Discontinuity Coefficients by Country Border

This figure shows the heterogeneous effects by country border estimated using a Poisson model. It shows the regression discontinuity coefficients of the Brazilian effect, $\gamma$, on the percentage of annual forest loss by year, from equation (1) with linear running variables and $25 \mathrm{~km}$ bandwidth. The upper panel shows our main specification with the whole border (the solid line) and the border segments with Bolivia and Peru, and the bottom panel (b) shows estimates for the border segments with Colombia, Venezuela and the countries in the Northern border (i.e., Guyana, Suriname and French Guiana), presented in Table A7. The vertical bars represent 95 percent confidence intervals. 


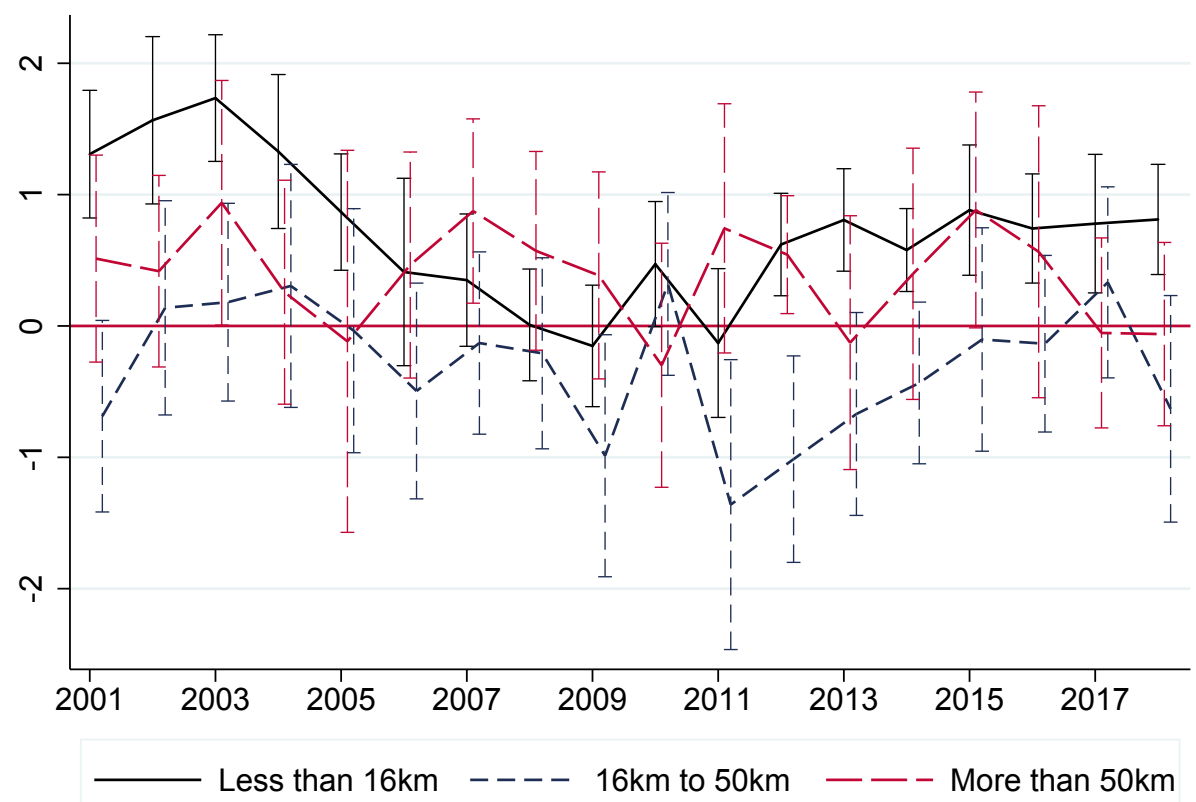

(a) Distance to roads

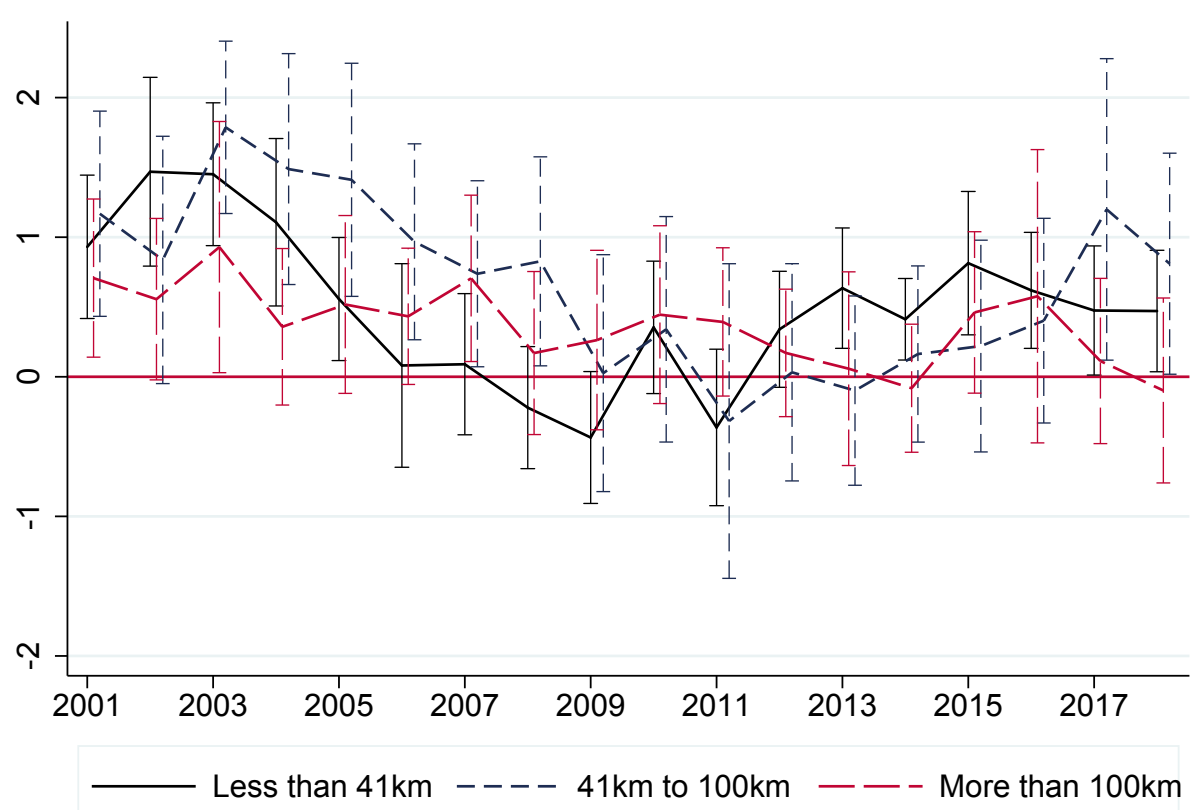

(b) Distance to villages

Figure A4: Regression Discontinuity Coefficients by Distance to Roads and Villages

This figure shows the heterogeneous effects by distance to roads (panel a) and villages (panel b) estimated using a Poisson model. It shows the regression discontinuity coefficients of the Brazilian effect, $\gamma$, on the percentage of annual forest loss by year, from equation (1) with linear running variables and $25 \mathrm{~km}$ bandwidth. Solid lines depict the results restricting the sample to the first $1 / 3$ percentile of distance, dashed dark line the $2 / 3$ percentile and the red long-dashed lines the top $1 / 3$ percentile. All estimates presented in Table $A 8$ and A9. The vertical bars represent 95 percent confidence intervals. 


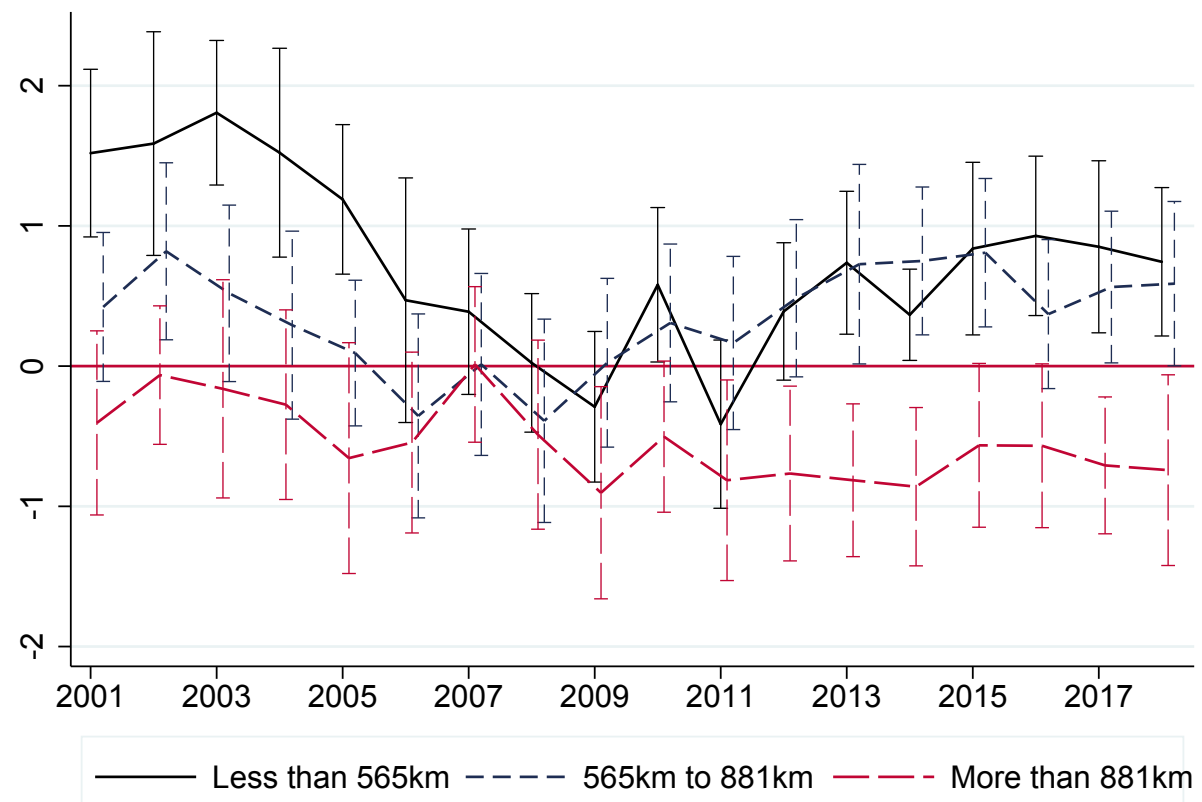

Figure A5: Regression Discontinuity Coefficients by Distance to Enforcement Base

This figure shows the heterogeneous effects by distance to enforcement base (IBAMA/MMA center) estimated using a Poisson model. It shows the regression discontinuity coefficients of the Brazilian effect, $\gamma$, on the percentage of annual forest loss by year, from equation (1) with linear running variables and $25 \mathrm{~km}$ bandwidth. Solid lines depict the results restricting the sample to the first $1 / 3$ percentile of distance, dashed dark line the $2 / 3$ percentile and the red long-dashed lines the top $1 / 3$ percentile. All estimates presented in Table $A 10$. The vertical bars represent 95 percent confidence intervals. 


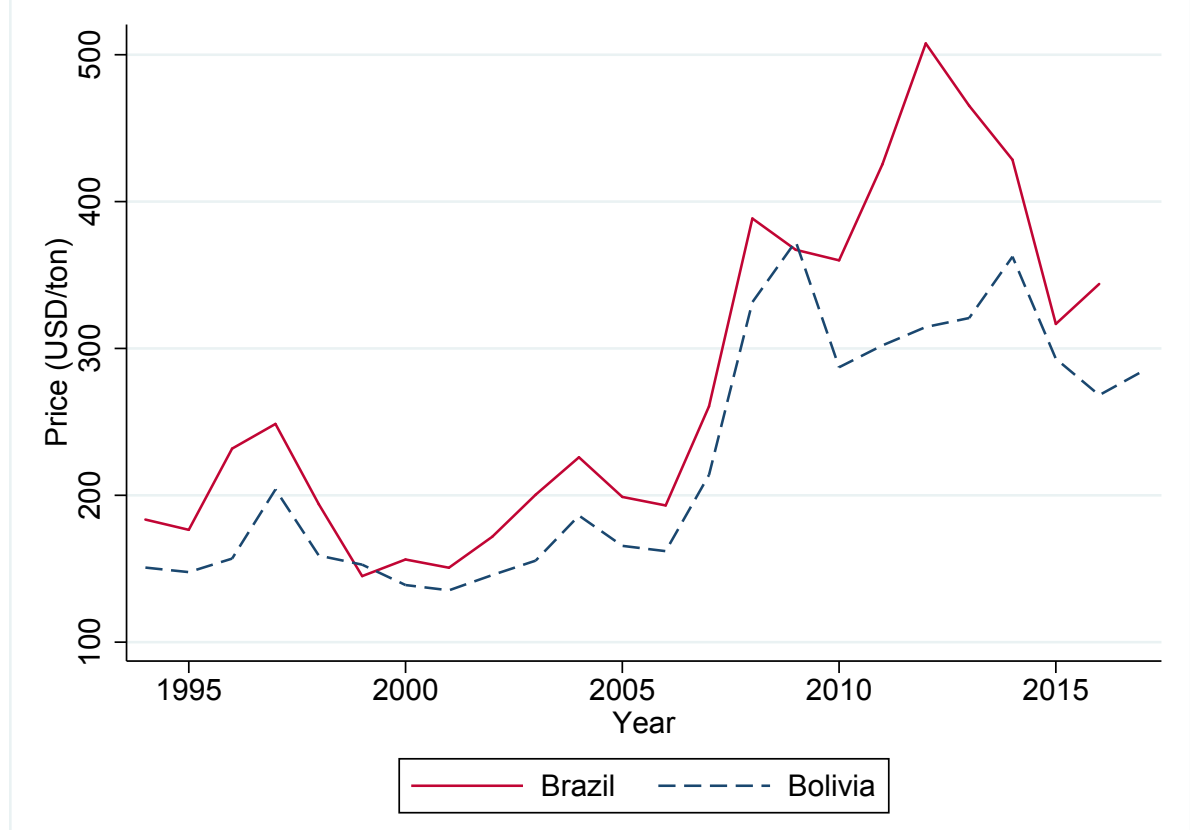

Figure A6: Farmgate Soybean Prices in Brazil and Bolivia

This figure shows average producer prices for soybeans in Brazil and neighboring Bolivia, using data from the FAO. 


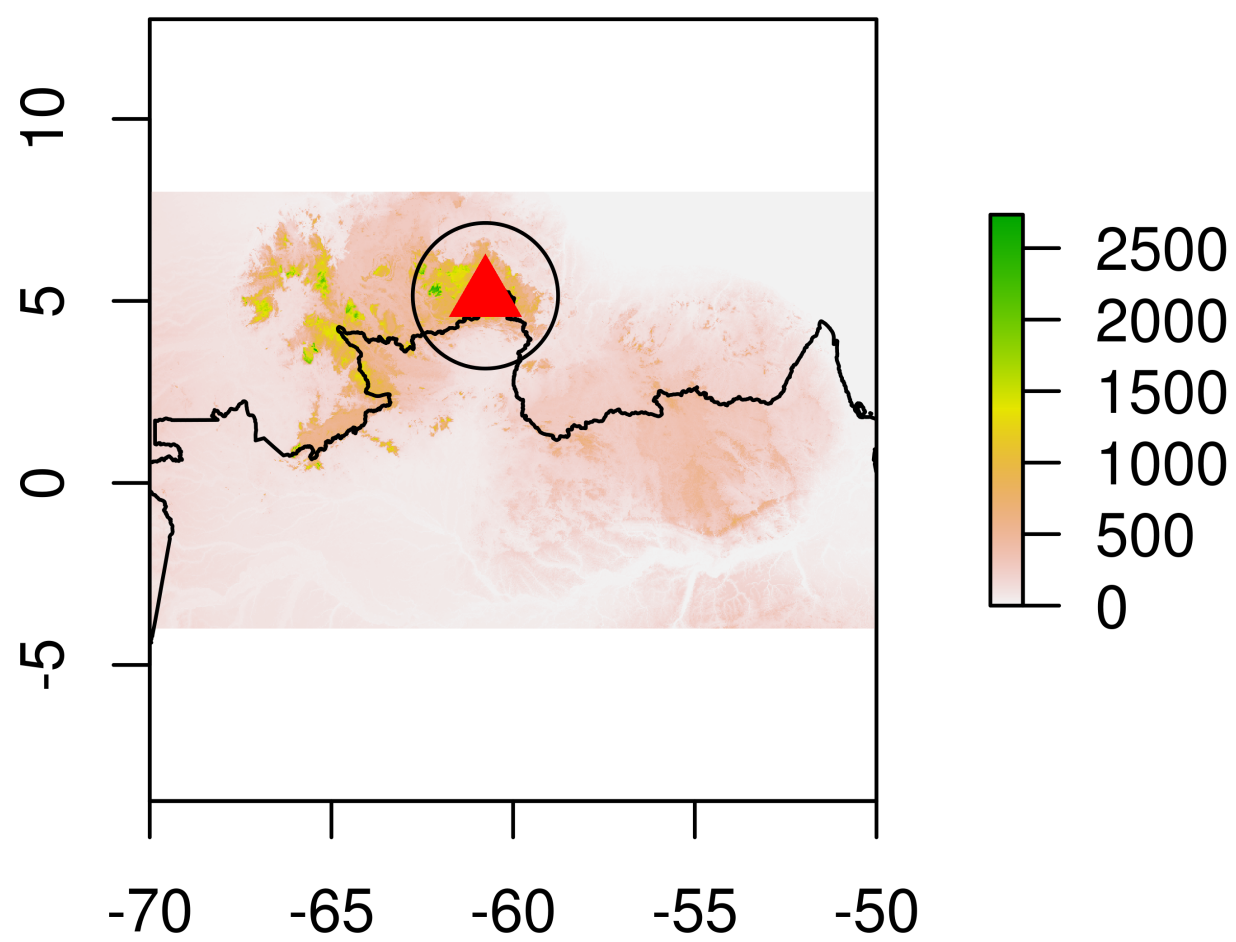

(a) Map of elevation with $220 \mathrm{~km}$ radius buffer around the peak of Mount Roraima

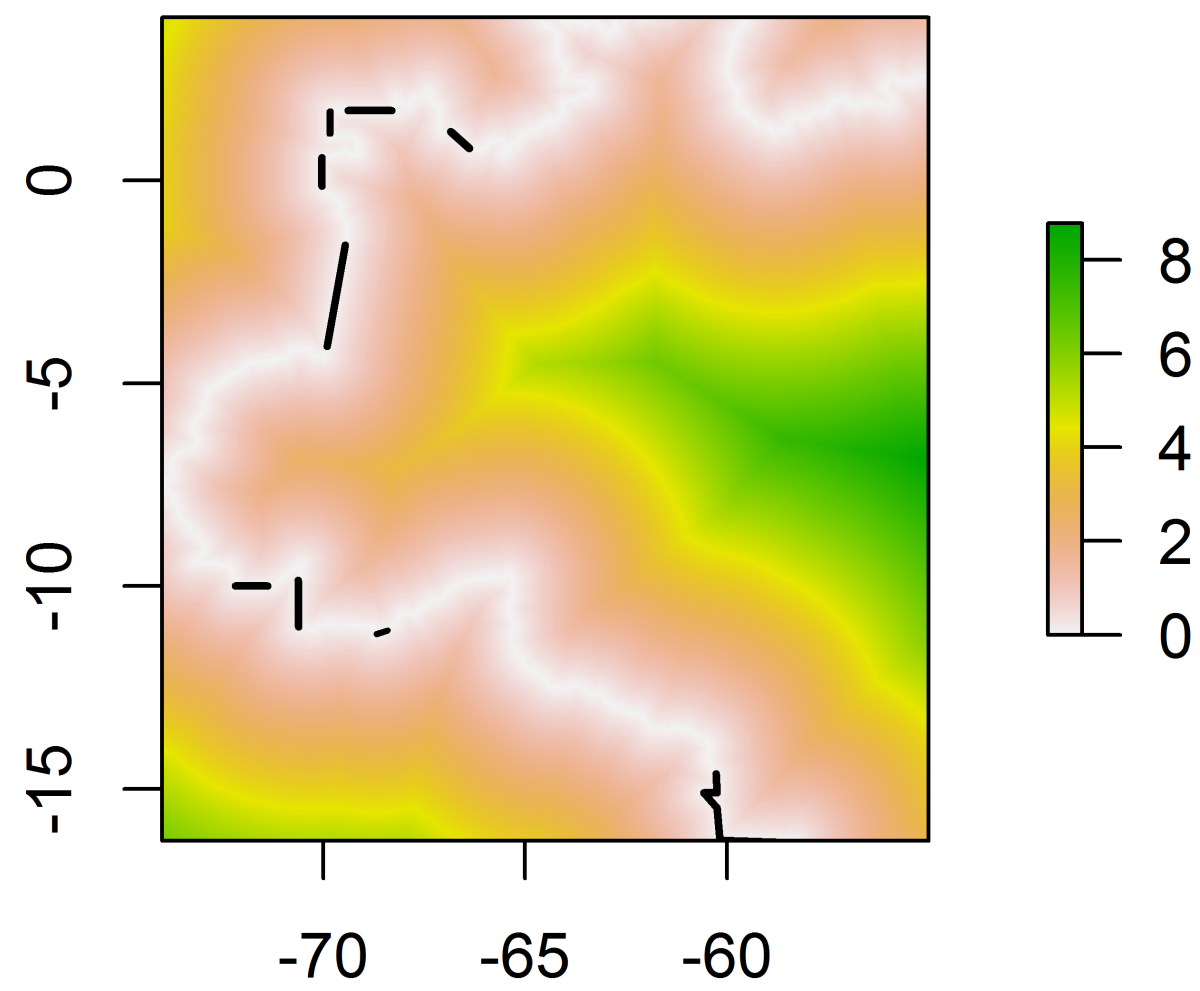

(b) Map of Distance From Border with Artificial Borders Highlighted

Figure A7: Maps

The map in the upper panel shows the elevation (in shades as in the scale) with a $220 \mathrm{~km}$ radius buffer around the peak of Mount Roraima in the North segment of Brazilian border with Venezuela and Guyana. The map in the bottom panel shows the distance from border measures in latitude degrees (in shades as in the scale). The area in white is distance zero. The highlighted sections in black are the areas where the border is artificially delimited, i.e., where borders are not set by a natural landmark. 
Table A1: Summary Statistics

\begin{tabular}{|c|c|c|c|c|}
\hline & \multicolumn{2}{|c|}{ Bandwidth $25 \mathrm{~km}$} & \multicolumn{2}{|c|}{ Bandwidth 100km } \\
\hline & $\begin{array}{c}\text { Brazil } \\
(1)\end{array}$ & $\begin{array}{c}\text { Abroad } \\
(2)\end{array}$ & $\begin{array}{c}\text { Brazil } \\
(3)\end{array}$ & $\begin{array}{c}\text { Abroad } \\
(4)\end{array}$ \\
\hline \# Observations & $14,809,321$ & $14,841,401$ & $52,646,804$ & $52,636,853$ \\
\hline Forest cover in $2000(\%)$ & 83.30 & 89.36 & 84.29 & 90.37 \\
\hline Forest loss in $2001(\%)$ & .313 & .058 & .329 & .047 \\
\hline Forest loss in $2002(\%)$ & .381 & .052 & .381 & .042 \\
\hline Forest loss in $2003(\%)$ & .312 & .049 & .322 & .037 \\
\hline Forest loss in $2004(\%)$ & .427 & .071 & .372 & .063 \\
\hline Forest loss in $2005(\%)$ & .483 & .121 & .437 & .096 \\
\hline Forest loss in $2006(\%)$ & .197 & .071 & .223 & .059 \\
\hline Forest loss in $2007(\%)$ & .172 & .092 & .172 & .071 \\
\hline Forest loss in $2008(\%)$ & .171 & .106 & .187 & .097 \\
\hline Forest loss in $2009(\%)$ & .145 & .112 & .153 & .088 \\
\hline Forest loss in $2010(\%)$ & .219 & .120 & .213 & .115 \\
\hline Forest loss in $2011(\%)$ & .147 & .138 & .163 & .092 \\
\hline Forest loss in $2012(\%)$ & .186 & .107 & .191 & .105 \\
\hline Forest loss in $2013(\%)$ & .122 & .068 & .124 & .062 \\
\hline Forest loss in $2014(\%)$ & .220 & .099 & .234 & .087 \\
\hline Forest loss in $2015(\%)$ & .184 & .077 & .201 & .071 \\
\hline Forest loss in $2016(\%)$ & .372 & .175 & .444 & .189 \\
\hline Forest loss in $2017(\%)$ & .341 & .160 & .353 & .173 \\
\hline Protected Areas (\%) & 48.2 & .8 & 46.3 & .2 \\
\hline Private Non-PAs (\%) & 14.7 & - & 18.6 & - \\
\hline Unclaimed Non-PAs (\%) & 37.1 & - & 35.1 & - \\
\hline Area in Black Listed Counties (\%) & 3.0 & - & 1.5 & - \\
\hline Dist. to enforcement (km) & 705.3 & 741 & 648.4 & 788 \\
\hline Dist. to water $(\mathrm{km})$ & 44.2 & 46.1 & 41.3 & 38.3 \\
\hline Dist. to urban $(\mathrm{km})$ & 89.9 & 92.9 & 88.6 & 92.7 \\
\hline Dist. to roads $(\mathrm{km})$ & 40.4 & 47.2 & 34.6 & 50.8 \\
\hline Roads within 5km (\%) & 14.9 & 15.1 & 16.9 & 12.9 \\
\hline Mount Roraima's Buffer (\%) & 7.30 & 7.9 & 5.2 & 8.1 \\
\hline
\end{tabular}

This table presents the summary statistics of the variables used in the paper. Each column present results for a different bandwidth or segment of the border in Brazil and Abroad (bordering countries) as indicated. The bandwidth of $25 \mathrm{~km}$ is the average optimal bandwidth of our dependent variables. Units of observations are 120-meter pixels around the whole Brazilian Amazon border. 
Table A2: Covariates Balance Check - Linear Polynomials

\begin{tabular}{|c|c|c|c|c|c|c|c|c|c|c|c|c|}
\hline & \multirow{2}{*}{\multicolumn{3}{|c|}{$\begin{array}{l}\text { Land } \\
\text { Slope }\end{array}$}} & \multicolumn{9}{|c|}{ Distance from } \\
\hline & & & & \multicolumn{3}{|c|}{ Urban Area } & \multicolumn{3}{|c|}{ Water } & \multicolumn{3}{|c|}{ Roads } \\
\hline & (1) & $(2)$ & (3) & (4) & (5) & (6) & (7) & (8) & (9) & (10) & (11) & (12) \\
\hline \multicolumn{13}{|c|}{ Panel A. Maximum Distance from Border $25 \mathrm{~km}$} \\
\hline \multirow[t]{2}{*}{$\operatorname{Brazil}(\gamma)$} & -.014 & -.014 & -.024 & -.001 & -.002 & -.001 & -.003 & -.003 & -.003 & 0 & -.002 & -.001 \\
\hline & $(.151)$ & $(.163)$ & $(.138)$ & $(.061)$ & $(.064)$ & $(.066)$ & $(.028)$ & $(.03)$ & $(.031)$ & $(.034)$ & $(.036)$ & $(.036)$ \\
\hline \multicolumn{13}{|c|}{ Panel B. $N$} \\
\hline \multirow[t]{2}{*}{$\operatorname{Brazil}(\gamma)$} & -.105 & -.113 & -.121 & .001 & .001 & .001 & 0 & 0 & 0 & .002 & .002 & .002 \\
\hline & $(.23)$ & $(.25)$ & $(.226)$ & $(.058)$ & $(.061)$ & $(.062)$ & $(.028)$ & $(.03)$ & $(.03)$ & $(.031)$ & $(.033)$ & $(.034)$ \\
\hline \multirow{3}{*}{$\begin{array}{l}\text { Panel C. } \\
\text { Brazil }(\gamma)\end{array}$} & Maximur & Distar & from & order 50 & $\mathrm{~km}$ & & & & & & & \\
\hline & -.013 & -.013 & -.007 & -.011 & -.011 & -.011 & -.01 & -.014 & -.011 & -.011 & -.015 & -.012 \\
\hline & $(.102)$ & $(.11)$ & $(.093)$ & $(.061)$ & $(.065)$ & $(.066)$ & $(.027)$ & $(.029)$ & $(.029)$ & $(.034)$ & $(.036)$ & $(.036)$ \\
\hline \multirow{3}{*}{$\begin{array}{l}\text { Panel D } \\
\text { Brazil }(\gamma)\end{array}$} & Maximur & Distar & ce from & order 10 & $k m$ & & & & & & & \\
\hline & .046 & .05 & .066 & -.023 & -.025 & -.028 & -.037 & -.047 & -.039 & -.035 & -.039 & -.045 \\
\hline & $(.069)$ & $(.074)$ & $(.065)$ & $(.052)$ & $(.054)$ & $(.056)$ & $(.022)$ & $(.023)$ & $(.024)$ & $(.028)$ & $(.03)$ & $(.031)$ \\
\hline \multicolumn{2}{|c|}{ Excl. Mount Roraima } & Yes & & & Yes & & & Yes & & & Yes & \\
\hline \multicolumn{2}{|c|}{ Artificial Borders } & & Yes & & & Yes & & & Yes & & & Yes \\
\hline
\end{tabular}

This table presents the regression estimates of the Brazilian dummy, $\gamma$, on land slope (columns 1-3), distance from water (columns 4-6), distance from roads (columns 7-9) and distance from urban areas (columns 10-12), from equation (1) with linear polynomials. Panel A refers to the optimal bandwidth of (Imbens and Kalyanaraman, 2012), and Panel $\mathrm{B}$ refers to the average optimal bandwidth and bias-correction bandwidth (Calonico et al., 2014) of our dependent variables. Bias-correction bandiwtdh are $53 \mathrm{~km}, 23 \mathrm{~km}, 100 \mathrm{~km}$, and $100 \mathrm{~km}$, respectively. Units of observations are 120-meter pixels around the whole Brazilian Amazon border. We present results for three segments as indicated in the columns: the whole border, the border excluding a $220 \mathrm{~km}$ buffer around the peak of Mount Roraima, and artificial borders only. Number of observations (whole border; excluding Mount Roraima; artificial border): Panel A (6,239,668; $5,750,468 ; 558,906)$, Panel B $(20,537,712 ; 18,961,163 ; 2,016,027)$, Panel C $(56,024,296 ; 51,982,251 ; 5,029,133)$, Panel D $(105,283,103 ; 98,296,660 ; 7,289,279)$. Standard errors clustered at $25 \mathrm{~km}$ grids in parentheses, number of clusters for the respective border segments: Panel A $(301 ; 282 ; 39)$, Panel B $(223 ; 205 ; 27)$, Panel C (510; 480; 58), Panel D (788; $747 ; 72)$. Significance levels: $* 10 \%, * * 5 \%, * * * 1 \%$. 
Table A3: Results Forest Loss by Year

\begin{tabular}{|c|c|c|c|c|}
\hline \multirow[t]{2}{*}{ Dep. Variable } & \multicolumn{4}{|c|}{ Brazil $(\gamma)$ By Maximum Distance from Border } \\
\hline & $\begin{array}{c}25 \mathrm{~km} \\
(1)\end{array}$ & $\begin{array}{c}11 \mathrm{~km} \\
(2)\end{array}$ & $\begin{array}{c}50 \mathrm{~km} \\
(3)\end{array}$ & $\begin{array}{c}100 \mathrm{~km} \\
(4)\end{array}$ \\
\hline \multirow[t]{2}{*}{ Forest cover in $2000(\%)$} & $-3.893^{*}$ & -2.822 & $-4.801 * *$ & $-5.568 * *$ \\
\hline & $(1.92)$ & $(1.713)$ & $(1.965)$ & $(1.683)$ \\
\hline \multirow[t]{2}{*}{ Forest loss in $2001(\%)$} & $.105^{* *}$ & $.094^{* *}$ & $.170^{* * *}$ & $.216^{* * *}$ \\
\hline & $(.038)$ & $(.035)$ & $(.040)$ & $(.038)$ \\
\hline \multirow[t]{2}{*}{ Forest loss in $2002(\%)$} & $.216^{* * *}$ & $.171^{* * *}$ & $.274^{* * *}$ & $.295^{* * *}$ \\
\hline & $(.060)$ & $(.056)$ & $(.062)$ & $(.053)$ \\
\hline \multirow[t]{2}{*}{ Forest loss in $2003(\%)$} & $.204^{* * *}$ & $.131^{* * *}$ & $.234^{* * *}$ & $.227^{* * *}$ \\
\hline & $(.050)$ & $(.042)$ & $(.049)$ & $(.041)$ \\
\hline \multirow[t]{2}{*}{ Forest loss in $2004(\%)$} & $.221^{* * *}$ & $.130^{* *}$ & $.308^{* * *}$ & $.331^{* * *}$ \\
\hline & $(.062)$ & $(.055)$ & $(.061)$ & $(.052)$ \\
\hline \multirow[t]{2}{*}{ Forest loss in $2005(\%)$} & $.200^{*}$ & $.162^{*}$ & $.281^{* * *}$ & $.330^{* * *}$ \\
\hline & $(.088)$ & $(.081)$ & $(.083)$ & $(.071)$ \\
\hline \multirow[t]{2}{*}{ Forest loss in $2006(\%)$} & .044 & .056 & $.080^{*}$ & $.091^{* *}$ \\
\hline & $(.045)$ & $(.044)$ & $(.040)$ & $(.032)$ \\
\hline \multirow[t]{2}{*}{ Forest loss in $2007(\%)$} & .027 & -.015 & .050 & .058 \\
\hline & $(.031)$ & $(.030)$ & $(.031)$ & $(.026)$ \\
\hline \multirow[t]{2}{*}{ Forest loss in $2008(\%)$} & -.005 & -.043 & .030 & .040 \\
\hline & $(.048)$ & $(.064)$ & $(.038)$ & $(.028)$ \\
\hline \multirow[t]{2}{*}{ Forest loss in $2009(\%)$} & -.049 & $-.062^{*}$ & -.021 & .011 \\
\hline & $(.033)$ & $(.035)$ & $(.030)$ & $(.026)$ \\
\hline \multirow[t]{2}{*}{ Forest loss in $2010(\%)$} & .039 & -.022 & $.080 * *$ & $.081^{* *}$ \\
\hline & $(.039)$ & $(.042)$ & $(.037)$ & $(.032)$ \\
\hline \multirow[t]{2}{*}{ Forest loss in $2011(\%)$} & -.049 & -.049 & -.046 & -.015 \\
\hline & $(.040)$ & $(.032)$ & $(.040)$ & $(.034)$ \\
\hline \multirow[t]{2}{*}{ Forest loss in $2012(\%)$} & .026 & .005 & .051 & $.065^{*}$ \\
\hline & $(.028)$ & $(.027)$ & $(.028)$ & $(.025)$ \\
\hline \multirow[t]{2}{*}{ Forest loss in $2013(\%)$} & .029 & -.003 & $.045^{* *}$ & $.046^{* *}$ \\
\hline & $(.02)$ & $(.020)$ & $(.020)$ & $(.017)$ \\
\hline \multirow[t]{2}{*}{ Forest loss in $2014(\%)$} & .073 & .025 & $.085^{*}$ & $.107^{*}$ \\
\hline & $(.051)$ & $(.073)$ & $(.042)$ & $(.032)$ \\
\hline \multirow[t]{2}{*}{ Forest loss in $2015(\%)$} & $.071^{* *}$ & .010 & $.093^{* * *}$ & $.090^{* *}$ \\
\hline & $(.031)$ & $(.030)$ & $(.031)$ & $(.025)$ \\
\hline \multirow[t]{2}{*}{ Forest loss in $2016(\%)$} & $.119^{* *}$ & .070 & $.161^{* * *}$ & $.161^{* * *}$ \\
\hline & $(.051)$ & $(.048)$ & $(.050)$ & $(.046)$ \\
\hline \multirow[t]{2}{*}{ Forest loss in $2017(\%)$} & $.167^{* *}$ & .092 & $.174^{* * *}$ & $.165^{* * *}$ \\
\hline & $(.066)$ & $(.052)$ & $(.061)$ & $(.048)$ \\
\hline \multirow[t]{2}{*}{ Forest loss in $2018(\%)$} & $.073^{*}$ & .037 & $.093^{* *}$ & $.116^{* *}$ \\
\hline & $(.035)$ & $(.035)$ & $(.037)$ & $(.033)$ \\
\hline
\end{tabular}

This table presents the regression estimates of the Brazilian effect, $\gamma$, on the percentage of forest cover in 2000 (row 1) and annual forest loss (remaining rows), from equation (1) with linear polynomials and triangular kernel. All regressions control for the slope of the terrain and distance to water. Each column shows results for a different bandwidth, as indicated. Column 1 refers to the average optimal bandwidth and bias-correction bandwidth (Imbens and Kalyanaraman, 2012) of our dependent variables, and column 2 refers to the optimal bandwidth of (Calonico et al., 2014). Bias-correction bandwidths are $53 \mathrm{~km}, 23 \mathrm{~km}, 100 \mathrm{~km}$, and $100 \mathrm{~km}$, respectively. Units of observations are 120-meter pixels around the whole Brazilian Amazon border. Standard errors clustered at 25km grids in parentheses. Number of clusters and observations: 1,094 and 31,071,838 (column 1), 708 and 13,871,677 (column 2), 1,660 and 56,024,296 (column 3), 2,759 and 105,283,103 (column 4). Significance levels: *10\%, **5\%, ***1\%. 
Table A4: Robustness - OLS Model - Controls - Quadratic Polynomial - Mount Roraima

\begin{tabular}{|c|c|c|c|c|}
\hline \multirow[t]{2}{*}{ Dep. Variable } & \multicolumn{4}{|c|}{$\operatorname{Brazil}(\gamma)$} \\
\hline & (1) & $(2)$ & (3) & (4) \\
\hline \multirow[t]{2}{*}{ Forest cover in $2000(\%)$} & $-3.949^{*}$ & $-4.566^{* * *}$ & -2.906 & $-9.693^{* * *}$ \\
\hline & $(1.977)$ & $(1.647)$ & $(1.776)$ & $(1.799)$ \\
\hline \multirow[t]{2}{*}{ Forest loss in $2001(\%)$} & $.105^{* *}$ & $.114^{* *}$ & $.084^{* *}$ & $.313^{* * *}$ \\
\hline & $(.038)$ & $(.041)$ & $(.036)$ & $(.036)$ \\
\hline \multirow[t]{2}{*}{ Forest loss in $2002(\%)$} & $.217^{* * *}$ & $.233^{* * *}$ & $.152^{* * *}$ & $.53^{* * *}$ \\
\hline & $(.061)$ & $(.065)$ & $(.055)$ & $(.058)$ \\
\hline \multirow[t]{2}{*}{ Forest loss in $2003(\%)$} & $.205^{* * *}$ & $.219^{* * *}$ & $.153^{* * *}$ & $.452^{* * *}$ \\
\hline & $(.05)$ & $(.053)$ & $(.045)$ & $(.048)$ \\
\hline \multirow[t]{2}{*}{ Forest loss in $2004(\%)$} & $.222^{* * *}$ & $.24^{* * *}$ & $.136^{* *}$ & $.553^{* * *}$ \\
\hline & $(.063)$ & $(.067)$ & $(.06)$ & $(.06)$ \\
\hline \multirow[t]{2}{*}{ Forest loss in $2005(\%)$} & $.2^{*}$ & $.217^{* *}$ & $.176^{*}$ & $.502^{* * *}$ \\
\hline & $(.088)$ & $(.095)$ & $(.087)$ & $(.085)$ \\
\hline \multirow[t]{2}{*}{ Forest loss in $2006(\%)$} & .045 & .05 & .04 & $.141^{* * *}$ \\
\hline & $(.045)$ & $(.048)$ & $(.046)$ & $(.044)$ \\
\hline \multirow[t]{2}{*}{ Forest loss in $2007(\%)$} & .027 & .029 & -.005 & $.091^{* * *}$ \\
\hline & $(.031)$ & $(.033)$ & $(.033)$ & $(.03)$ \\
\hline \multirow[t]{2}{*}{ Forest loss in $2008(\%)$} & -.004 & -.006 & -.039 & .038 \\
\hline & $(.049)$ & $(.052)$ & $(.063)$ & $(.047)$ \\
\hline \multirow[t]{2}{*}{ Forest loss in $2009(\%)$} & -.049 & -.053 & $-.066^{*}$ & -.04 \\
\hline & $(.034)$ & $(.036)$ & $(.039)$ & $(.033)$ \\
\hline \multirow[t]{2}{*}{ Forest loss in $2010(\%)$} & .04 & .044 & -.025 & $.136^{* * *}$ \\
\hline & $(.04)$ & $(.042)$ & $(.044)$ & $(.038)$ \\
\hline \multirow[t]{2}{*}{ Forest loss in $2011(\%)$} & -.048 & -.052 & -.046 & -.054 \\
\hline & $(.041)$ & $(.043)$ & $(.039)$ & $(.039)$ \\
\hline \multirow[t]{2}{*}{ Forest loss in $2012(\%)$} & .026 & .03 & .001 & $.094^{* * *}$ \\
\hline & $(.028)$ & $(.03)$ & $(.028)$ & $(.027)$ \\
\hline \multirow[t]{2}{*}{ Forest loss in $2013(\%)$} & .029 & .032 & -.007 & $.082^{* * *}$ \\
\hline & $(.02)$ & $(.022)$ & $(.021)$ & $(.019)$ \\
\hline \multirow[t]{2}{*}{ Forest loss in $2014(\%)$} & .073 & .081 & .032 & $.187^{* * *}$ \\
\hline & $(.053)$ & $(.056)$ & $(.07)$ & $(.051)$ \\
\hline \multirow[t]{2}{*}{ Forest loss in $2015(\%)$} & $.071^{* *}$ & $.079^{* *}$ & .014 & $.175^{* * *}$ \\
\hline & $(.032)$ & $(.034)$ & $(.03)$ & $(.031)$ \\
\hline \multirow[t]{2}{*}{ Forest loss in $2016(\%)$} & $.12^{* *}$ & $.139^{* *}$ & .036 & $.285^{* * *}$ \\
\hline & $(.052)$ & $(.054)$ & $(.053)$ & $(.05)$ \\
\hline \multirow[t]{2}{*}{ Forest loss in $2017(\%)$} & $.167^{* *}$ & $.185^{* *}$ & $.114^{*}$ & $.34^{* * *}$ \\
\hline & $(.067)$ & $(.071)$ & $(.057)$ & $(.064)$ \\
\hline \multirow[t]{2}{*}{ Forest loss in $2018(\%)$} & $.074^{*}$ & $.081^{*}$ & .043 & $.189^{* * *}$ \\
\hline & $(.036)$ & $(.038)$ & $(.038)$ & $(.034)$ \\
\hline Polinomial & Linear & Linear & Quadratic & Linear \\
\hline Controls & None & Geographic & Geographic & Geo. \& Infrastructure \\
\hline Excl. Mount Roraima & No & Yes & No & No \\
\hline
\end{tabular}

This table presents the regression estimates of the Brazilian effect, $\gamma$, on the percentage of forest cover in 2000 (row 1 ) and annual forest loss (remaining rows), from equation (1). Bandwidth 25km, bias-correction bandwidth $53 \mathrm{~km}$, and triangular kernel as in column 1 Table A3. All regressions, except column 1, control for the slope of the terrain and distance to water. Column 2 uses a subset of the border excluding a 220km buffer around the peak of Mount Roraima. Column 3 uses quadratic polynomials of distance to the border; other columns use linear polynomials. Column 4 further controls for the distance from roads and distance from urban areas. Units of observations are 120-meter pixels. Standard errors clustered at 25km grids in parentheses. Number of observations: 1,094 and 31,071,838 (columns 1, 3 and 4), 1,017 and 28,705,843 (column 2). Significance $12^{2}$ vels: *10\%, **5\%, ***1\%. 
Table A5: Robustness - Artificial Borders - Rectangular Kernel - Poisson Model

\begin{tabular}{|c|c|c|c|c|}
\hline \multirow[t]{3}{*}{ Dep. Variable } & \multicolumn{4}{|c|}{$\operatorname{Brazil}(\gamma)$} \\
\hline & \multicolumn{2}{|c|}{ OLS Model } & \multicolumn{2}{|c|}{ Poisson Model } \\
\hline & (1) & $(2)$ & (3) & $(4)$ \\
\hline \multirow[t]{2}{*}{ Forest cover in $2000(\%)$} & $-9.811^{*}$ & $-4.407^{*}$ & $-.047 * * *$ & $-.126^{*}$ \\
\hline & (5.363) & (2.069) & $(.017)$ & $(.065)$ \\
\hline \multirow[t]{2}{*}{ Forest loss in $2001(\%)$} & $.222^{*}$ & $.131^{* *}$ & $.989^{* * *}$ & $1.547^{* * *}$ \\
\hline & $(.115)$ & $(.043)$ & $(.221)$ & $(.436)$ \\
\hline \multirow[t]{2}{*}{ Forest loss in $2002(\%)$} & .312 & $.246^{* * *}$ & $1.381^{* * *}$ & $1.854^{* * *}$ \\
\hline & $(.187)$ & $(.07)$ & $(.292)$ & $(.554)$ \\
\hline \multirow[t]{2}{*}{ Forest loss in $2003(\%)$} & $.426^{*}$ & $.225^{* * *}$ & $1.531^{* * *}$ & $1.561^{* * *}$ \\
\hline & $(.222)$ & $(.053)$ & $(.224)$ & $(.296)$ \\
\hline \multirow[t]{2}{*}{ Forest loss in $2004(\%)$} & $.593^{* * *}$ & $.263^{* * *}$ & $1.165^{* * *}$ & $2.574^{* * *}$ \\
\hline & $(.209)$ & $(.066)$ & $(.267)$ & $(.411)$ \\
\hline \multirow[t]{2}{*}{ Forest loss in $2005(\%)$} & .107 & $.228^{* *}$ & $.714^{* * *}$ & .341 \\
\hline & $(.089)$ & (.09) & $(.217)$ & $(.445)$ \\
\hline \multirow[t]{2}{*}{ Forest loss in $2006(\%)$} & .124 & .048 & .261 & .371 \\
\hline & $(.158)$ & $(.046)$ & $(.322)$ & $(.672)$ \\
\hline \multirow[t]{2}{*}{ Forest loss in $2007(\%)$} & .029 & .036 & .248 & .151 \\
\hline & $(.108)$ & (.033) & $(.224)$ & $(.427)$ \\
\hline \multirow[t]{2}{*}{ Forest loss in $2008(\%)$} & -.208 & .012 & -.039 & -.703 \\
\hline & $(.319)$ & $(.043)$ & $(.204)$ & $(.459)$ \\
\hline \multirow{2}{*}{ Forest loss in $2009(\%)$} & $-.205^{*}$ & -.037 & -.299 & $-1.222^{* *}$ \\
\hline & $(.114)$ & $(.033)$ & $(.21)$ & $(.521)$ \\
\hline \multirow[t]{2}{*}{ Forest loss in $2010(\%)$} & -.144 & $.076^{*}$ & $.411^{* *}$ & -.236 \\
\hline & $(.24)$ & $(.04)$ & $(.209)$ & $(.578)$ \\
\hline \multirow[t]{2}{*}{ Forest loss in $2011(\%)$} & -.101 & -.048 & -.331 & -.61 \\
\hline & $(.09)$ & $(.044)$ & $(.259)$ & $(.535)$ \\
\hline \multirow[t]{2}{*}{ Forest loss in $2012(\%)$} & -.014 & .043 & .267 & .049 \\
\hline & $(.052)$ & $(.029)$ & $(.184)$ & $(.493)$ \\
\hline \multirow[t]{2}{*}{ Forest loss in $2013(\%)$} & .025 & $.046^{* *}$ & $.463^{* *}$ & .462 \\
\hline & $(.073)$ & $(.021)$ & $(.186)$ & $(.695)$ \\
\hline \multirow[t]{2}{*}{ Forest loss in $2014(\%)$} & .019 & .086 & $.351^{* * *}$ & .436 \\
\hline & $(.042)$ & $(.047)$ & $(.131)$ & $(.419)$ \\
\hline \multirow[t]{2}{*}{ Forest loss in $2015(\%)$} & -.166 & $.094^{* * *}$ & $.679^{* * *}$ & -.294 \\
\hline & (.138) & $(.035)$ & $(.219)$ & $(.499)$ \\
\hline \multirow[t]{2}{*}{ Forest loss in $2016(\%)$} & -.028 & $.167^{* * *}$ & $.616^{* * *}$ & .613 \\
\hline & $(.172)$ & $(.054)$ & $(.178)$ & $(.621)$ \\
\hline \multirow[t]{2}{*}{ Forest loss in $2017(\%)$} & -.237 & $.187^{* *}$ & $.65^{* * *}$ & -.334 \\
\hline & $(.254)$ & $(.071)$ & $(.232)$ & $(.745)$ \\
\hline \multirow[t]{2}{*}{ Forest loss in $2018(\%)$} & .056 & $.088^{* *}$ & $.494^{* * *}$ & .013 \\
\hline & $(.175)$ & $(.038)$ & $(.191)$ & $(.618)$ \\
\hline Artificial Border Only & Yes & No & No & Yes \\
\hline Kernel & Triangular & Rectangular & Rectangular & Rectangular \\
\hline
\end{tabular}

This table presents the regression estimates of the Brazilian effect, $\gamma$, on the percentage of forest cover in 2000 (row 1) and annual forest loss (remaining rows), from equation (1) with linear polynomials. Bandwidth 25km and biascorrection bandwidth $53 \mathrm{~km}$ as in column 1 Table A3. All regressions control for the slope of the terrain and distance to water. Columns 1 and 4 uses a subset of the border to the areas around artificial borders (i.e., straight line borders). Column 1 uses a triangular kernel, other columns use rectangular kernel. Columns 3 and 4 use a Poisson model instead of OLS. Units of observations are 120-meter pixels. Standard errors clustered at $25 \mathrm{~km}$ grids in parentheses. Number of observations: 1,094 and 31,071,838 (columns 2 and 3), 129 and 3,134,194 (columns 1 and 4). Significance levels: $* 10 \%, * * 5 \%, * * * 1 \%$. 
Table A6: Heterogeneous Effect by Land Type (Poisson model)

\begin{tabular}{|c|c|c|c|}
\hline \multirow[t]{2}{*}{ Dep. Variable } & \multicolumn{3}{|c|}{$\operatorname{Brazil}(\gamma)$} \\
\hline & $\begin{array}{c}\text { Protected } \\
\text { Areas } \\
(1)\end{array}$ & $\begin{array}{c}\text { Private and } \\
\text { Non-Protected Areas } \\
(2)\end{array}$ & $\begin{array}{c}\text { Unclaimed and } \\
\text { Non-Protected Areas } \\
(3)\end{array}$ \\
\hline Forest cover in $2000(\%)$ & $\begin{array}{l}.05 * * * \\
(.019)\end{array}$ & $\begin{array}{c}-.383^{* * *} \\
(.061)\end{array}$ & $\begin{array}{c}-.077^{* * *} \\
(.029)\end{array}$ \\
\hline Forest loss in $2001(\%)$ & $\begin{array}{l}-.265 \\
(.411)\end{array}$ & $\begin{array}{c}2.558 * * * \\
(.226)\end{array}$ & $\begin{array}{l}.63^{* *} \\
(.253)\end{array}$ \\
\hline Forest loss in $2002(\%)$ & $\begin{array}{c}-.5 \\
(.428)\end{array}$ & $\begin{array}{c}2.943^{* * *} \\
(.314)\end{array}$ & $\begin{array}{c}.962^{* * *} \\
(.3)\end{array}$ \\
\hline Forest loss in $2003(\%)$ & $\begin{array}{l}-.204 \\
(.492)\end{array}$ & $\begin{array}{c}3.042^{* * *} \\
(.226)\end{array}$ & $\begin{array}{c}1.158^{* * *} \\
(.275)\end{array}$ \\
\hline Forest loss in $2004(\%)$ & $\begin{array}{c}-.961^{* * *} \\
(.354)\end{array}$ & $\begin{array}{c}2.817^{* * * *} \\
(.28)\end{array}$ & $\begin{array}{l}.686^{* *} \\
(.299)\end{array}$ \\
\hline Forest loss in $2005(\%)$ & $\begin{array}{c}-1.742^{* * *} \\
(.428)\end{array}$ & $\begin{array}{c}2.509^{* * *} \\
(.229)\end{array}$ & $\begin{array}{c}.322 \\
(.247)\end{array}$ \\
\hline Forest loss in $2006(\%)$ & $\begin{array}{c}-1.444^{* * *} \\
(.423)\end{array}$ & $\begin{array}{c}1.576^{* * *} \\
(.358)\end{array}$ & $\begin{array}{l}.147 \\
(.389)\end{array}$ \\
\hline Forest loss in $2007(\%)$ & $\begin{array}{c}-.966^{* * *} \\
(.25)\end{array}$ & $\begin{array}{c}1.428^{* * *} \\
(.264)\end{array}$ & $\begin{array}{r}.073 \\
(.282)\end{array}$ \\
\hline Forest loss in $2008(\%)$ & $\begin{array}{c}-1.511^{* * *} \\
(.391)\end{array}$ & $\begin{array}{c}1.201^{* * * *} \\
(.256)\end{array}$ & $\begin{array}{l}-.219 \\
(.213)\end{array}$ \\
\hline Forest loss in $2009(\%)$ & $\begin{array}{c}-1.07 * * * \\
(.257)\end{array}$ & $\begin{array}{c}.769^{* * *} \\
(.269)\end{array}$ & $\begin{array}{c}-.709^{* * *} \\
(.231)\end{array}$ \\
\hline Forest loss in $2010(\%)$ & $\begin{array}{l}-.018 \\
(.36)\end{array}$ & $\begin{array}{c}1.492^{* * *} \\
(.25)\end{array}$ & $\begin{array}{l}-.029 \\
(.24)\end{array}$ \\
\hline Forest loss in $2011(\%)$ & $\begin{array}{c}-1.359^{* * *} \\
(.284)\end{array}$ & $\begin{array}{l}.693^{* *} \\
(.314)\end{array}$ & $\begin{array}{c}-.581^{* *} \\
(.278)\end{array}$ \\
\hline Forest loss in $2012(\%)$ & $\begin{array}{c}-.483^{* *} \\
(.203)\end{array}$ & $\begin{array}{c}1.534^{* * *} \\
(.265)\end{array}$ & $\begin{array}{l}-.108 \\
(.218)\end{array}$ \\
\hline Forest loss in $2013(\%)$ & $\begin{array}{c}-.822^{* * *} \\
(.207)\end{array}$ & $\begin{array}{c}1.947^{* * *} \\
(.275)\end{array}$ & $\begin{array}{c}.18 \\
(.198)\end{array}$ \\
\hline Forest loss in $2014(\%)$ & $\begin{array}{c}-.577^{* *} \\
(.282)\end{array}$ & $\begin{array}{c}1.411^{* * * *} \\
(.256)\end{array}$ & $\begin{array}{r}.276 \\
(.193)\end{array}$ \\
\hline Forest loss in $2015(\%)$ & $\begin{array}{c}-.888^{* * *} \\
(.246)\end{array}$ & $\begin{array}{c}2.139 * * * \\
(.293)\end{array}$ & $\begin{array}{l}.235 \\
(.22)\end{array}$ \\
\hline Forest loss in $2016(\%)$ & $\begin{array}{l}-.252 \\
(.308)\end{array}$ & $\begin{array}{c}1.997^{* * *} \\
(.216)\end{array}$ & $\begin{array}{r}.239 \\
(.187)\end{array}$ \\
\hline Forest loss in $2017(\%)$ & $\begin{array}{l}.509 \\
(.456)\end{array}$ & $\begin{array}{c}1.577^{* * *} \\
(.277)\end{array}$ & $\begin{array}{l}.304 \\
(.241)\end{array}$ \\
\hline Forest loss in $2018(\%)$ & $\begin{array}{c}-.885^{* * *} \\
(.246)\end{array}$ & $\begin{array}{c}1.83^{* * *} \\
(.276)\end{array}$ & $\begin{array}{l}.421^{*} \\
(.223)\end{array}$ \\
\hline
\end{tabular}

This table presents the Poisson regression estimates of the Brazilian effect, $\gamma$, on the percentage of forest cover in 2000 (row 1) and annual forest loss (remaining rows), from equation (1) with linear polynomials and rectangular kernel. All regressions control for the slope of the terrain and distance to water. Maximum Distance from Border $25 \mathrm{~km}$. Each column refers to different land types within Brazil. Units of observations are 120-meter pixels. Standard errors clustered at $25 \mathrm{~km}$ grids in parentheses. Number of clusters and of observations: 980 and 23,043,139 (Panel A), 870 and 17,833,657 (Panel B), 974 and 21,289,806 (Panel C). Significance levels: *10\%, **5\%, ***1\%. 
Table A7: Heterogeneous Effect by Country Border (Poisson model)

\begin{tabular}{|c|c|c|c|c|c|}
\hline \multirow[t]{2}{*}{ Dep. Variable } & \multicolumn{5}{|c|}{ Brazil $(\gamma)$ By Border Segment } \\
\hline & $\begin{array}{c}\text { Bolivia } \\
\text { (1) }\end{array}$ & $\begin{array}{c}\text { Peru } \\
\text { (2) }\end{array}$ & Colombia & $\begin{array}{c}\text { Venezuela } \\
\text { (4) }\end{array}$ & $\begin{array}{l}\text { Guyana, } \\
\text { Suriname, and } \\
\text { French Guyane } \\
\end{array}$ \\
\hline Forest cover in $2000(\%)$ & $\begin{array}{c}-.271^{* * *} \\
(.046)\end{array}$ & $\begin{array}{l}-.003 \\
(.002)\end{array}$ & $\begin{array}{r}.002 \\
(.003)\end{array}$ & $\begin{array}{l}.045^{* *} \\
(.021)\end{array}$ & $\begin{array}{l}-.009 \\
(.051)\end{array}$ \\
\hline Forest loss in $2001(\%)$ & $\begin{array}{c}1.199^{* * *} \\
(.273)\end{array}$ & $\begin{array}{c}.56 \\
(.554)\end{array}$ & $\begin{array}{l}-.242 \\
(.373)\end{array}$ & $\begin{array}{r}.096 \\
(.472)\end{array}$ & $\begin{array}{l}.802^{*} \\
(.423)\end{array}$ \\
\hline Forest loss in $2002(\%)$ & $\begin{array}{c}1.549^{* * *} \\
(.349)\end{array}$ & $\begin{array}{c}.4 \\
(.524)\end{array}$ & $\begin{array}{r}.175 \\
(.312)\end{array}$ & $\begin{array}{r}.456 \\
(.699)\end{array}$ & $\begin{array}{r}.676 \\
(.475)\end{array}$ \\
\hline Forest loss in $2003(\%)$ & $\begin{array}{c}1.571^{* * *} \\
(.241)\end{array}$ & $\begin{array}{r}.463 \\
(.485)\end{array}$ & $\begin{array}{l}-.544 \\
(.432)\end{array}$ & $\begin{array}{l}1.044^{*} \\
(.569)\end{array}$ & $\begin{array}{c}1.232^{* *} \\
(.491)\end{array}$ \\
\hline Forest loss in $2004(\%)$ & $\begin{array}{c}1.315^{* * *} \\
(.308)\end{array}$ & $\begin{array}{c}.43 \\
(.539)\end{array}$ & $\begin{array}{l}-.115 \\
(.408)\end{array}$ & $\begin{array}{r}.091 \\
(.383)\end{array}$ & $\begin{array}{r}.279 \\
(.547)\end{array}$ \\
\hline Forest loss in $2005(\%)$ & $\begin{array}{c}.846^{* * *} \\
(.246)\end{array}$ & $\begin{array}{c}.599 \\
(.482)\end{array}$ & $\begin{array}{c}-1.005^{*} \\
(.537)\end{array}$ & $\begin{array}{l}-.289 \\
(.446)\end{array}$ & $\begin{array}{c}1.171^{* * * *} \\
(.408)\end{array}$ \\
\hline Forest loss in $2006(\%)$ & $\begin{array}{l}.357 \\
(.387)\end{array}$ & $\begin{array}{r}.146 \\
(.418)\end{array}$ & $\begin{array}{l}-.627 \\
(.379)\end{array}$ & $\begin{array}{r}.051 \\
(.512)\end{array}$ & $\begin{array}{r}.775 \\
(.478)\end{array}$ \\
\hline Forest loss in $2007(\%)$ & $\begin{array}{r}.228 \\
(.275)\end{array}$ & $\begin{array}{l}.514 \\
(.392)\end{array}$ & $\begin{array}{r}.178 \\
(.359)\end{array}$ & $\begin{array}{l}.676^{* *} \\
(.309)\end{array}$ & $\begin{array}{l}.566^{*} \\
(.317)\end{array}$ \\
\hline Forest loss in $2008(\%)$ & $\begin{array}{l}-.062 \\
(.232)\end{array}$ & $\begin{array}{l}-.287 \\
(.444)\end{array}$ & $\begin{array}{l}-.463 \\
(.437)\end{array}$ & $\begin{array}{l}.216 \\
(.38)\end{array}$ & $\begin{array}{l}.793^{* *} \\
(.343)\end{array}$ \\
\hline Forest loss in $2009(\%)$ & $\begin{array}{l}-.295 \\
(.257)\end{array}$ & $\begin{array}{l}.218 \\
(.414)\end{array}$ & $\begin{array}{c}-.909^{* *} \\
(.421)\end{array}$ & $\begin{array}{r}.227 \\
(.446)\end{array}$ & $\begin{array}{r}.379 \\
(.316)\end{array}$ \\
\hline Forest loss in $2010(\%)$ & $\begin{array}{l}.586^{* *} \\
(.261)\end{array}$ & $\begin{array}{l}-.438 \\
(.407)\end{array}$ & $\begin{array}{c}-.22 \\
(.302)\end{array}$ & $\begin{array}{r}.396 \\
(.416)\end{array}$ & $\begin{array}{r}.071 \\
(.283)\end{array}$ \\
\hline Forest loss in $2011(\%)$ & $\begin{array}{l}-.349 \\
(.29)\end{array}$ & $\begin{array}{c}.2 \\
(.476)\end{array}$ & $\begin{array}{l}-.613 \\
(.495)\end{array}$ & $\begin{array}{l}-.193 \\
(.438)\end{array}$ & $\begin{array}{r}.183 \\
(.262)\end{array}$ \\
\hline Forest loss in $2012(\%)$ & $\begin{array}{l}.471^{*} \\
(.244)\end{array}$ & $\begin{array}{r}.16 \\
(.39)\end{array}$ & $\begin{array}{c}-.812^{* *} \\
(.378)\end{array}$ & $\begin{array}{l}.011 \\
(.29)\end{array}$ & $\begin{array}{c}.31^{*} \\
(.174)\end{array}$ \\
\hline Forest loss in $2013(\%)$ & $\begin{array}{c}.861^{* * *} \\
(.228)\end{array}$ & $\begin{array}{r}.095 \\
(.437)\end{array}$ & $\begin{array}{r}-.56 \\
(.384)\end{array}$ & $\begin{array}{r}.255 \\
(.379)\end{array}$ & $\begin{array}{l}-.724 \\
(.577)\end{array}$ \\
\hline Forest loss in $2014(\%)$ & $\begin{array}{c}.498^{* * *} \\
(.171)\end{array}$ & $\begin{array}{r}.338 \\
(.386)\end{array}$ & $\begin{array}{l}-.757^{*} \\
(.391)\end{array}$ & $\begin{array}{l}.02 \\
(.3)\end{array}$ & $\begin{array}{l}-.422 \\
(.267)\end{array}$ \\
\hline Forest loss in $2015(\%)$ & $\begin{array}{c}.896^{* * *} \\
(.286)\end{array}$ & $\begin{array}{l}.807^{* *} \\
(.367)\end{array}$ & $\begin{array}{l}-.504 \\
(.385)\end{array}$ & $\begin{array}{r}.046 \\
(.366)\end{array}$ & $\begin{array}{r}.305 \\
(.334)\end{array}$ \\
\hline Forest loss in $2016(\%)$ & $\begin{array}{c}.962^{* * *} \\
(.268)\end{array}$ & $\begin{array}{c}.069 \\
(.455)\end{array}$ & $\begin{array}{l}-.353 \\
(.375)\end{array}$ & $\begin{array}{l}.344 \\
(.5)\end{array}$ & $\begin{array}{l}-.179 \\
(.408)\end{array}$ \\
\hline Forest loss in $2017(\%)$ & $\begin{array}{c}.873^{* * *} \\
(.282)\end{array}$ & $\begin{array}{c}.327 \\
(.407)\end{array}$ & $\begin{array}{l}-.525 \\
(.378)\end{array}$ & $\begin{array}{r}.161 \\
(.381)\end{array}$ & $\begin{array}{l}-.241 \\
(.364)\end{array}$ \\
\hline Forest loss in $2018(\%)$ & $\begin{array}{c}.845^{* * *} \\
(.248)\end{array}$ & $\begin{array}{l}.418 \\
(.456)\end{array}$ & $\begin{array}{l}-.577 \\
(.445)\end{array}$ & $\begin{array}{l}-.141 \\
(.337)\end{array}$ & $\begin{array}{l}-.022 \\
(.376)\end{array}$ \\
\hline
\end{tabular}

This table presents the Poisson regression estimates of the Brazilian effect, $\gamma$, on the percentage of forest cover in 2000 (row 1) and annual forest loss (remaining rows), from equation (1) with linear polynomials and rectangular kernel. All regressions control for the slope of the terrain and distance to water; bandwidth 25km. Each column refers to results across different country border segments. Units of observations are 120-meter pixels. Standard errors clustered at $25 \mathrm{~km}$ grids in parentheses. Number of clusters and observations: 275 and 7,670,348 (column 1), 206 and 5,760,641 (column 2), 187 and 5,283,074 (column 3), 196 and 5,497,980 (column 4), and 249 and 6,853,075 (column 5). Significance levels: $* 10 \%, * * 5 \%, * * * 1 \%$. 
Table A8: Heterogeneous Effect by Distance to Roads (Poisson model)

\begin{tabular}{|c|c|c|c|}
\hline & \multicolumn{3}{|c|}{ Brazil $(\gamma)$ By Distance to Roads } \\
\hline & $\begin{array}{c}\text { Within } 16 \mathrm{~km} \\
(1)\end{array}$ & Between $16 \mathrm{~km}$ and $50 \mathrm{~km}$ & $\begin{array}{l}\text { More than } 50 \mathrm{~km} \\
(3)\end{array}$ \\
\hline \multirow[t]{2}{*}{ Forest cover in $2000(\%)$} & $-.149 * * *$ & $-.042^{*}$ & .007 \\
\hline & $(.044)$ & $(.024)$ & $(.005)$ \\
\hline \multirow[t]{2}{*}{ Forest loss in $2001(\%)$} & $1.308^{* * *}$ & $-.687^{*}$ & .513 \\
\hline & $(.248)$ & $(.372)$ & $(.402)$ \\
\hline \multirow[t]{2}{*}{ Forest loss in $2002(\%)$} & $1.566^{* * *}$ & .138 & .417 \\
\hline & $(.325)$ & $(.416)$ & $(.372)$ \\
\hline \multirow[t]{2}{*}{ Forest loss in $2003(\%)$} & $1.735^{* * *}$ & .181 & $.938^{* *}$ \\
\hline & $(.246)$ & $(.384)$ & $(.475)$ \\
\hline \multirow{2}{*}{ Forest loss in $2004(\%)$} & $1.328^{* * *}$ & .305 & .257 \\
\hline & $(.299)$ & $(.472)$ & $(.435)$ \\
\hline \multirow[t]{2}{*}{ Forest loss in $2005(\%)$} & $.867^{* * *}$ & -.036 & -.117 \\
\hline & $(.226)$ & $(.474)$ & $(.742)$ \\
\hline \multirow{2}{*}{ Forest loss in $2006(\%)$} & .411 & -.495 & .464 \\
\hline & $(.364)$ & $(.419)$ & $(.439)$ \\
\hline \multirow[t]{2}{*}{ Forest loss in $2007(\%)$} & .349 & -.13 & $.875^{* *}$ \\
\hline & $(.257)$ & $(.354)$ & $(.358)$ \\
\hline \multirow[t]{2}{*}{ Forest loss in $2008(\%)$} & .008 & -.208 & .572 \\
\hline & $(.217)$ & $(.371)$ & $(.386)$ \\
\hline \multirow[t]{2}{*}{ Forest loss in $2009(\%)$} & -.152 & $-.988^{* *}$ & .385 \\
\hline & $(.236)$ & $(.47)$ & $(.402)$ \\
\hline \multirow[t]{2}{*}{ Forest loss in $2010(\%)$} & $.471^{*}$ & .32 & -.299 \\
\hline & $(.243)$ & $(.355)$ & $(.474)$ \\
\hline \multirow[t]{2}{*}{ Forest loss in $2011(\%)$} & -.13 & $-1.36^{* *}$ & .743 \\
\hline & $(.289)$ & $(.563)$ & $(.484)$ \\
\hline \multirow[t]{2}{*}{ Forest loss in $2012(\%)$} & $.62^{* * *}$ & $-1.014^{* *}$ & $.543^{* *}$ \\
\hline & $(.199)$ & $(.401)$ & $(.229)$ \\
\hline \multirow[t]{2}{*}{ Forest loss in $2013(\%)$} & $.807^{* * *}$ & $-.67^{*}$ & -.127 \\
\hline & (.199) & $(.394)$ & $(.493)$ \\
\hline \multirow[t]{2}{*}{ Forest loss in $2014(\%)$} & $.578 * * *$ & -.434 & .397 \\
\hline & $(.161)$ & $(.314)$ & $(.488)$ \\
\hline \multirow[t]{2}{*}{ Forest loss in $2015(\%)$} & $.882^{* * *}$ & -.103 & $.883^{*}$ \\
\hline & $(.253)$ & $(.434)$ & $(.458)$ \\
\hline \multirow[t]{2}{*}{ Forest loss in $2016(\%)$} & $.742^{* * *}$ & -.135 & .565 \\
\hline & $(.212)$ & $(.343)$ & $(.567)$ \\
\hline \multirow[t]{2}{*}{ Forest loss in $2017(\%)$} & $.779 * * *$ & .332 & -.053 \\
\hline & $(.269)$ & $(.371)$ & $(.369)$ \\
\hline \multirow[t]{2}{*}{ Forest loss in $2018(\%)$} & $.811^{* * *}$ & -.631 & -.062 \\
\hline & $(.214)$ & $(.44)$ & $(.356)$ \\
\hline
\end{tabular}

This table presents the Poisson regression estimates of the Brazilian effect, $\gamma$, on the percentage of forest cover in 2000 (row 1) and annual forest loss (remaining rows), from equation (1) with linear polynomials and rectangular kernel. All regressions control for the slope of the terrain and distance to water; bandwidth $25 \mathrm{~km}$. Each column refers to results across subsamples of pixels in different terciles distance to roads. Units of observations are 120-meter pixels. Standard errors clustered at 25km grids in parentheses. Number of clusters and observations: 505 and 10,356,924 (Panel A), 649 and 10,357,284 (Panel B), 446 and 10,357,630 (Panel C), 447 and 10,356,785 (Panel D), 541 and 10,357,574 (Panel E), and 415 and 10,357,479 (Panel F). Significance levels: *10\%, **5\%, ***1\%. 
Table A9: Heterogeneous Effect by Distance to Town or Village (Poisson model)

\begin{tabular}{|c|c|c|c|}
\hline & \multicolumn{3}{|c|}{ Brazil $(\gamma)$ By Distance to Town or Village } \\
\hline & $\begin{array}{l}\text { Within } 41 \mathrm{~km} \\
(1)\end{array}$ & Between $41 \mathrm{~km}$ and $100 \mathrm{~km}$ & More than $100 \mathrm{~km}$ \\
\hline \multirow[t]{2}{*}{ Forest cover in $2000(\%)$} & $-.113^{* *}$ & -.04 & 0 \\
\hline & $(.045)$ & $(.025)$ & $(.013)$ \\
\hline \multirow[t]{2}{*}{ Forest loss in $2001(\%)$} & $.931^{* * *}$ & $1.168^{* * *}$ & $.707^{* *}$ \\
\hline & $(.262)$ & $(.375)$ & $(.289)$ \\
\hline \multirow[t]{2}{*}{ Forest loss in $2002(\%)$} & $1.469 * * *$ & $.837^{*}$ & $.556^{*}$ \\
\hline & $(.345)$ & $(.452)$ & $(.295)$ \\
\hline \multirow{2}{*}{ Forest loss in $2003(\%)$} & $1.451^{* * *}$ & $1.787^{* * *}$ & $.929^{* *}$ \\
\hline & $(.261)$ & $(.315)$ & $(.459)$ \\
\hline \multirow[t]{2}{*}{ Forest loss in $2004(\%)$} & $1.107^{* * *}$ & $1.488^{* * *}$ & .358 \\
\hline & $(.306)$ & $(.422)$ & $(.286)$ \\
\hline \multirow{2}{*}{ Forest loss in $2005(\%)$} & $.557^{* *}$ & $1.411^{* * *}$ & .518 \\
\hline & $(.225)$ & $(.426)$ & $(.325)$ \\
\hline \multirow[t]{2}{*}{ Forest loss in $2006(\%)$} & .081 & $.967^{* * *}$ & $.433^{*}$ \\
\hline & $(.372)$ & $(.358)$ & $(.249)$ \\
\hline \multirow[t]{2}{*}{ Forest loss in $2007(\%)$} & .09 & $.738^{* *}$ & $.705^{* *}$ \\
\hline & $(.258)$ & $(.34)$ & $(.304)$ \\
\hline \multirow[t]{2}{*}{ Forest loss in $2008(\%)$} & -.221 & $.827^{* *}$ & .17 \\
\hline & $(.223)$ & $(.382)$ & $(.298)$ \\
\hline \multirow[t]{2}{*}{ Forest loss in $2009(\%)$} & $-.435^{*}$ & .026 & .263 \\
\hline & $(.241)$ & $(.433)$ & $(.328)$ \\
\hline \multirow[t]{2}{*}{ Forest loss in $2010(\%)$} & .354 & .34 & .445 \\
\hline & $(.242)$ & $(.412)$ & $(.325)$ \\
\hline \multirow[t]{2}{*}{ Forest loss in $2011(\%)$} & -.363 & -.317 & .393 \\
\hline & $(.286)$ & $(.575)$ & $(.271)$ \\
\hline \multirow[t]{2}{*}{ Forest loss in $2012(\%)$} & .34 & .032 & .171 \\
\hline & $(.212)$ & $(.397)$ & $(.233)$ \\
\hline \multirow[t]{2}{*}{ Forest loss in $2013(\%)$} & $.635^{* * *}$ & -.099 & .058 \\
\hline & $(.22)$ & $(.346)$ & $(.354)$ \\
\hline \multirow[t]{2}{*}{ Forest loss in $2014(\%)$} & $.412^{* * *}$ & .163 & -.082 \\
\hline & $(.149)$ & $(.322)$ & $(.234)$ \\
\hline \multirow[t]{2}{*}{ Forest loss in $2015(\%)$} & $.814^{* * *}$ & .22 & .461 \\
\hline & $(.262)$ & $(.387)$ & $(.295)$ \\
\hline \multirow[t]{2}{*}{ Forest loss in $2016(\%)$} & $.619^{* * *}$ & .402 & .577 \\
\hline & $(.212)$ & $(.374)$ & $(.536)$ \\
\hline \multirow[t]{2}{*}{ Forest loss in $2017(\%)$} & $.475^{* *}$ & $1.199^{* *}$ & .113 \\
\hline & $(.236)$ & $(.551)$ & $(.302)$ \\
\hline \multirow[t]{2}{*}{ Forest loss in $2018(\%)$} & $.471^{* *}$ & $.81^{* *}$ & -.098 \\
\hline & $(.222)$ & $(.404)$ & (.338) \\
\hline
\end{tabular}

This table presents the Poisson regression estimates of the Brazilian effect, $\gamma$, on the percentage of forest cover in 2000 (row 1) and annual forest loss (remaining rows), from equation (1) with linear polynomials and rectangular kernel. All regressions control for the slope of the terrain and distance to water; bandwidth $25 \mathrm{~km}$. Each column refers to results across subsamples of pixels in different terciles distance to town or village. Units of observations are 120-meter pixels. Standard errors clustered at $25 \mathrm{~km}$ grids in parentheses. Number of clusters and observations: 505 and 10,356,924 (Panel A), 649 and 10,357,284 (Panel B), 446 and 10,357,630 (Panel C), 447 and 10,356,785 (Panel D), 541 and 10,357,574 (Panel E), and 415 and 10,357,479 (Panel F). Significance levels: *10\%, **5\%, ***1\%. 
Table A10: Heterogeneous Effect by Distance to Enforcement (Poisson model)

\begin{tabular}{|c|c|c|c|}
\hline & \multicolumn{3}{|c|}{ Brazil $(\gamma)$ By Distance to Enforcement Base } \\
\hline & $\begin{array}{l}\text { Within } 565 \mathrm{~km} \\
\text { (1) }\end{array}$ & $\begin{array}{c}\text { Between } 565 \mathrm{~km} \text { and } 881 \mathrm{~km} \\
(2)\end{array}$ & More than $881 \mathrm{~km}$ \\
\hline \multirow[t]{2}{*}{ Forest cover in $2000(\%)$} & $-.16^{* * *}$ & .007 & .002 \\
\hline & $(.034)$ & $(.036)$ & $(.008)$ \\
\hline \multirow[t]{2}{*}{ Forest loss in $2001(\%)$} & $1.519^{* * *}$ & .422 & -.405 \\
\hline & $(.305)$ & $(.271)$ & $(.335)$ \\
\hline \multirow[t]{2}{*}{ Forest loss in $2002(\%)$} & $1.587^{* * *}$ & $.819^{* *}$ & -.064 \\
\hline & $(.407)$ & $(.322)$ & $(.252)$ \\
\hline \multirow[t]{2}{*}{ Forest loss in $2003(\%)$} & $1.807 * * *$ & .519 & -.162 \\
\hline & $(.263)$ & $(.321)$ & $(.397)$ \\
\hline \multirow[t]{2}{*}{ Forest loss in $2004(\%)$} & $1.522^{* * *}$ & .292 & -.275 \\
\hline & $(.38)$ & $(.342)$ & $(.345)$ \\
\hline \multirow[t]{2}{*}{ Forest loss in $2005(\%)$} & $1.189^{* * *}$ & .093 & -.656 \\
\hline & $(.272)$ & $(.265)$ & $(.42)$ \\
\hline \multirow[t]{2}{*}{ Forest loss in $2006(\%)$} & .47 & -.355 & -.545 \\
\hline & $(.445)$ & $(.371)$ & $(.329)$ \\
\hline \multirow[t]{2}{*}{ Forest loss in $2007(\%)$} & .388 & .012 & .012 \\
\hline & $(.301)$ & $(.331)$ & $(.283)$ \\
\hline \multirow[t]{2}{*}{ Forest loss in $2008(\%)$} & .023 & -.39 & -.489 \\
\hline & $(.252)$ & $(.37)$ & $(.344)$ \\
\hline \multirow[t]{2}{*}{ Forest loss in $2009(\%)$} & -.29 & .024 & $-.903^{* *}$ \\
\hline & $(.274)$ & $(.307)$ & $(.386)$ \\
\hline \multirow[t]{2}{*}{ Forest loss in $2010(\%)$} & $.58^{* *}$ & .308 & $-.503^{*}$ \\
\hline & $(.281)$ & $(.287)$ & $(.275)$ \\
\hline \multirow[t]{2}{*}{ Forest loss in $2011(\%)$} & -.414 & .165 & $-.814^{* *}$ \\
\hline & $(.306)$ & $(.315)$ & $(.365)$ \\
\hline \multirow[t]{2}{*}{ Forest loss in $2012(\%)$} & .39 & $.484^{*}$ & $-.766^{* *}$ \\
\hline & $(.25)$ & $(.286)$ & $(.318)$ \\
\hline \multirow[t]{2}{*}{ Forest loss in $2013(\%)$} & $.737 * * *$ & $.727^{* *}$ & $-.814^{* * *}$ \\
\hline & $(.26)$ & $(.363)$ & $(.278)$ \\
\hline \multirow[t]{2}{*}{ Forest loss in $2014(\%)$} & $.366^{* *}$ & $.75^{* * *}$ & $-.86^{* * *}$ \\
\hline & $(.166)$ & $(.269)$ & $(.288)$ \\
\hline \multirow[t]{2}{*}{ Forest loss in $2015(\%)$} & $.838^{* * *}$ & $.809 * * *$ & $-.565^{*}$ \\
\hline & $(.314)$ & $(.27)$ & $(.298)$ \\
\hline \multirow[t]{2}{*}{ Forest loss in $2016(\%)$} & $.929 * * *$ & .371 & $-.568^{*}$ \\
\hline & $(.29)$ & $(.271)$ & $(.298)$ \\
\hline \multirow[t]{2}{*}{ Forest loss in $2017(\%)$} & $.851^{* * *}$ & $.564^{* *}$ & $-.708 * * *$ \\
\hline & $(.313)$ & $(.276)$ & $(.249)$ \\
\hline \multirow[t]{2}{*}{ Forest loss in $2018(\%)$} & $.744^{* * *}$ & $.588^{* *}$ & $-.742^{* *}$ \\
\hline & $(.27)$ & $(.299)$ & $(.347)$ \\
\hline
\end{tabular}

This table presents the Poisson regression estimates of the Brazilian effect, $\gamma$, on the percentage of forest cover in 2000 (row 1) and annual forest loss (remaining rows), from equation (1) with linear polynomials and rectangular kernel. All regressions control for the slope of the terrain and distance to water; bandwidth $25 \mathrm{~km}$. Each column refers to results across subsamples of pixels in different terciles distance to enforcement base. Units of observations are 120 meter pixels. Standard errors clustered at $25 \mathrm{~km}$ grids in parentheses. Number of clusters and observations: 505 and 10,356,924 (Panel A), 649 and 10,357,284 (Panel B), 446 and 10,357,630 (Panel C), 447 and 10,356,785 (Panel D), 541 and 10,357,574 (Panel E), and 415 and 10,357,479 (Panel F). Significance levels: *10\%, **5\%, ***1\%. 


\section{B Additional Background Information}

\section{B.1 Timeline of Relevant Events in the Brazilian Amazon and Brazil- ian Environmental Policy}

1494 Treaty of Tordesillas, most of the Amazon belongs to the Spanish Crown.

1637 First big Portuguese expedition to the Amazon (two thousand people).

1750 Treaty of Madrid, Portugal gains control of most of the current Brazilian Amazon.

1851-1871 The precise limits of Brazilian border with Bolivia and Peru are set.

1870-1900 First Rubber Cycle. Government gave incentives to migrate to the region. First big migration influx. Migrants could work as rubber tappers, but could not own land.

1904 Brazil gains control of Acre state, in the border with Bolivia and Peru. Last borders defined in Treaty of Rio de Janeiro in1909.

1940-1945 Second Rubber Cycle (coincides with WWII). President Getulio Vargas promotes the "March to the West" and advertises the "New Eldorado".

1964-1980s Military Dictatorship promoted the occupation of the area.

1976 Regularization of land titling for properties under 60 thousand hectares that were occupied illegally but in "good faith".

$1978 \quad$ Population in the Legal Amazon 7 million people.

1980s Environmental concerns start to emerge and the main local environmental leader, Chico Mendes, is murdered in 1988.

1990s New large population influx with cattle ranching and soybean plantations expansion.

$2000 \quad$ Population in the Legal Amazon 21 million people.

2002 The Amazon Protected Area Program (ARPA) is created to expand the Brazilian National System of Protected Areas (SNUC) and to guarantee financial resources to promote sustainable development (Federal Decree 4.326/2002).

Creation of Ecological and Economic Zoning, EEZ, (Federal Decree 4297/2002).

2003 The first presidential mandate of Lula da Silva begins. Marina Silva is appointed Minister of the Environment.

The rural caucus in congress (the "ruralists") win 73 seats (14\% of the congress).

2004 In November, the Ministry of Environment launches the first phase of PPCDAm. ${ }^{17}$

\footnotetext{
${ }^{17}$ The first phase was originally planned to be implemented from April 2003.
} 
2004-08 Demarcation of the perimeter of new Conservation Units and Indigenous Lands; both are Protected Areas. ${ }^{18}$

Banning of over 60,000 illegal rural property titles.

Development of the remote-sensing system DETER by INPE.

2005 Demarcation of Conservation Units in the areas surrounding the highways BR-319 (Manaus - Porto Velho) and BR-163 (Tenente Portela - Santarém). ${ }^{19}$

2005-07 Georeferencing of more than 10 million hectares of public lands in black listed municipalities (none on the border). ${ }^{20}$

2005-07 18 operational basis from IBAMA are constructed. ${ }^{21}$

2006 Law on Public Forest Management (law 11.284/2006) enacted.

IBAMA's Center for Environmental Monitoring (CEMAM) fully functioning and operational centers receiving online deforestation data.

2007 Begins the second presidential mandate of Lula da Silva.

First Black Listed municipalities are defined (Decree 6.321/2007).

Ecological and Economic Zoning (EEZ)'s project for BR-163 completed.

The rural caucus in congress (the "ruralists") win 116 seats (22\% of the congress)

2008 Decree 6.514/2008 reestablished the directives to investigate and punish environmental infractions. It defines the administrative processes for environmental crimes, and introduced new mechanisms for law enforcement (e.g., seizure of equipment used for illegal activities).

Creation of the Sustainable Amazon Plan (PAS) with the aim to define guidelines for sustainable development in the region. This is an strategic plan focused on economic and environmental development of the region, prioritizing the creation of jobs and income for the local population.

Marina Silva resigns as minister five days after the PAS was released, given the "difficulties that she had been facing to advance with the environmental agenda in the federal government." ${ }^{22}$

Implementation of "Operation Fire Arc" through public security actions.

\footnotetext{
${ }^{18}$ Creation of 46 PAs (24 mi ha).

${ }^{19}$ Law $11132 / 2005$.

${ }^{20}$ Altamira, Anapu, Novo Progresso, Medicilândia, Santarém, Esperança, Pacajá, Cachoeira do Piriá, CoroaciParaná, and Alto Alegre

${ }^{21}$ An operational base a local headquarters that centralize the local PPDCAm actions in the area.

${ }^{22}$ Extract from the resignation letter: https://noticias.uol.com.br/ultnot/2008/05/13/ult23u2297.jhtm
} 
2008-10 "Operation Green Arc", supported by eight Federal Ministries (Agriculture, Agrarian Development, Environment, Cities, National Integration, Labor, Justice, and Health) instituted policies and actions to promote sustainable development in 43 black listed municipalities.

Resolution conditioning the concession of rural credit in the Amazon Biome upon legal and environmental compliance. ${ }^{23}$

2009 Land titles of federal public land given to squatters with smallholdings.

Seven municipalities added to the list of black listed municipalities.

2010-15 Second phase of Amazon Protected Area Program (ARPA), with the goal to create 13.5 million ha of new PAs.

2011 The first presidential term of Dilma Rousseff begins.

The rural caucus in congress (the "ruralists") win 142 seats (28\% of the congress)

Seven municipalities added to the list of black listed municipalities.

2012 New Forest Code (Law 12.651/2012) grant amnesty for small properties (440 ha or less) that had deforested the Legal Reserve area in their properties before 2008 .

Law 12.615/2012 institutes the Environmental Rural Registry (CAR), a mandatory registration for all rural properties.

The number of IBAMA's enforcement officers is reduced by $13.1 \%$ relative to 2010 .

2013 The Prosecutor General of Brazil contested the constitutionality of 23 items of the New Forest Code, among them the amnesty for past deforestation.

Massive social mobilizations all over the country.

2014 Election year, and "Car Wash" operation.

The number of IBAMA's enforcement officers falls by $24 \%$ relative to 2010 .

IBAMA's budget cut by $34.2 \%$ relative the previous year.

2015 The second presidential term of Dilma Rousseff begins.

The rural caucus in congress (the "ruralists") win 207 seats (38\% of the congress) GDP shrinks 3.7\%.

2016 Impeachment of Ms. Rousseff. Begins the presidential mandate of Michel Temer. GDP shrinks 3.5\%.

\footnotetext{
${ }^{23}$ Resolution 3545, introduced by the Brazilian National Monetary Council (CMN).
} 
IBAMA lose additional $3.5 \%$ of enforcement officers and $13.5 \%$ of its budget (relative to 2014).

2017 Law (no. 3.465/2017) simplifies the requirement for land regularization and titling of occupied public land in rural and urban areas.

2018 The Supreme Court sanctioned the New Forestry Code, including the amnesty item.

\section{B.2 Timeline of Relevant Policy Changes in Neighboring Countries}

\section{B.2.1 Bolivia}

1996 Bolivia Forest Law (No. 1700) regulates the use of forest resources with guidelines for forest management plans (Supreme Decree 24453).

1997 Creation of Bolivian Forestry Superintendent (Superintendencia Forestal) to enforce the Forest Law. Decree declaring that the land rights of indigenous communities have precedence over concession-holders' rights.

2008 The National Holistic Forest Management Plan sets the initial ideas of President Evo Morales forest policy. Creation of economic and financial incentives for Community Forest Organizations (Organizaciones Forestales Comunitarias, OFC) to comply with forest management plans (Supreme Decree 29643).

2010 The Rights of Mother Earth Law (No. 071) declares Mother Earth the titleholder of inherent rights of the land. The new law promotes resource nationalism, and opposes the commodification of nature. National Program of Forestation and Reforestation created (Supreme Decree 0443). Bolivia politically rejects REDD+.

2012 Revision of and creation of legal framework for Law of Rights of Mother Earth (No. $300)$.

Proposes the Joint Mitigation and Adaptation Mechanism as an alternative to REDD ++ .

2013 ABT Resolution 250 outlines the requirement for Forest and Land Holistic Management Plans (PGIBT).

\section{B.2.2 Peru}

20012001 Forests and Wildlife Law (No. 27308) set first regulations for sustainable use of forest and wildlife resources.

2004 National Forest Strategy is made official. Alto Purus national park established on part of Brazilian boarder. 
2010 Action Plan for Adaptation and Mitigation Against Climate Change describes policy proposals in relation to climate change.

2011 New Forests and Wildlife Law (No. 29763) set the fundamental rights and duties related to forest inventory. National parks and conservation areas are "national patrimony." Law suspended waiting for accompanying regulation.

2014 Approval of the Mechanisms of Compensation for Services to Ecosystems (No. 30215).

2015 Final decrees approved setting the norms governing New Forests and Wildlife Law (No. 29763), which is effectively enacted the National Policy for Wildlife and Forests (PNFFS).

2016 The National Forestry and Climate Change Strategy is released, providing an unifying plan and policy objectives for mitigation and adaptation of climate change.

The Action Plan on Gender and Climate Change was approved (Executive Decree No. 012-2016-MINAM).

2018 Approval of the Framework Law on Climate Change (No. 30754/2018).

\section{B.2.3 Colombia}

1959 Law 2 introduced environmental planning and established the Zonas de Reserva Forestal (ZRF).

1974 The Natural Resource Code (Decree 2811) defines different uses for forest areas.

1993 Law 99 established the National Environmental System (Sistema Nacional Ambiental/SINA) and the Ministry of Environment and Sustainable Development (Ministerio de Ambiente y Desarrollo Sostenible/MADS). Law 70 gives afro-Colombian communities the right to the sustainable use of natural resources without the need of a license.

2000 Definition of the current National Forestry Policy (CONPES 3824 of 1996, and PNDF of 2000), with emphasis on zoning forest areas by permitted use, and sustainable use as a method of conservation.

$2006 \quad$ New General Forestry Law (Ley General Forestal) enacted in 2006 but declared unconstitutional in 2008. Environmental organizations criticized the new law for weakening timber licensing and transportation requirements.

2010 Decree 622 of 1977 established the national scheme of protected areas. Decree 2372 of 2010 created the National Parks Authority. 
2011 National REDD+ Strategy are part of President Santos Government's National Development Plan and were enacted into law (Law 1450).

2012 The Colombian Low-Carbon Development Strategy (ECDBC) launched aimed at promoting efficient low-carbon growth.

2013 Decree 953 from May 2013 established the first scheme for payment of environmental services (PES) in Colombia for the protection of water sources.

$2014 \quad$ FARC declares ceasefire following the peace negotiations started in 2012.

2018 Definition of the guidelines for the management of climate change (Law no. 1931) and publication of the Green Growth Policy strategic plan.

\section{B.2.4 Guyana}

$1998 \quad$ Forests Act regulates the cutting and removal of forest produce.

2007 Creation of the Guyana Forestry Commission to develop forest policy, enforcement, and certification of forest products.

2009 Low Carbon Development Strategy (LCDS) outlines an action plan to enable the transition of the country to a low-carbon economy.

2010 Enactment of The Forests Act (No. 6/2009), which repeals the 1998 Forests Act. Creates Protected Areas and sets a framework for land use regulation.

2011 Creation of the Guyanese National Forest Plan to implement the Forests Act 2009.

2017 Approval of the framework document for the Guyana Green State Development Strategy, which build on LCDS form 2009.

\section{B.2.5 Suriname}

1992 The Forest Management Act sets the requirements for the production and export of timber and non-timber products.

2006 National Forest Policy approved in the scope of the Forest Management Act, regulating both economic activity and land use.

2009 Interim strategic action plan to strengthen sustainable forest management, creating the Environmental Assessment Guidelines for logging, mining, and agriculture. However, an environmental impact assessment is mandatory.

2015 The National Climate Change Policy, Strategy and Action Plan launched outlining the government strategy on climate change mitigation and adaptation until 2021. 


\section{B.3 Background}

\section{B.3.1 Environmental Regulation in the Brazilian Amazon}

Until the 1960s, the Brazilian Amazon's native vegetation was largely preserved and inhospitable, popularly known as the "Green Hell" (Inferno Verde). The area had a small and sparse population living at subsistence levels, primarily involved in the extraction of rubber, as well as an indigenous population. Between 1964 and 1985, the military government promoted the occupation of the region by non-indigenous people with large infrastructure construction projects - e.g., by building roads and hydroelectric power plants - and by promoting the titling of occupied productive land (Pfaff, 1999). Consequently, a substantial number of migrants moved to the Amazon area, creating a boom of cattle ranching in the region.

Environmental consequences were not a central concern of Brazil during this period. Indeed, the Ministry of Environment (MMA) was created only in 1985, and the Brazilian Environmental Protection Agency (IBAMA) only in 1989. Even after the creation of IBAMA, and despite the enactment of the first Environmental Crimes Act in 1998, penalties for deforestation and squatting on unclaimed land were weak, and there was little coordination among federal agencies attempting to enforce these laws. On net, between the 1980s and 2004, the deforested area grew from $6 \%$ to $16 \%$ of total forest land in the Brazilian Amazon (MMA, 2013).

\section{B.3.2 The Action Plan for the Prevention and Control of Deforestation in the Legal Amazon (PPCDAm)}

The government of president Lula da Silva brought a new light to the environmental agenda in 2003, with the appointment of Marina Silva as Minister of the Environment. In 2004, the Brazilian federal government launched the Action Plan for the Prevention and Control of Deforestation in the Legal Amazon (PPCDAm) to crack down on deforestation in the Amazon. PPCDAm led to changes in both the legal sanctions for deforestation, as well as substantial changes in the enforcement of environmental regulation. In particular, a new remote-sensing system for environmental monitoring and enforcement was created (DETER), which in turn fed coordinated enforcement actions between many government institutions (see more details in Assunção et al., 2013).

In sum, while the vast majority of deforestation in the Amazon was illegal prior to 2005, the de jure legal sanctions associated with deforestation substantially increased in 2005.

Yet despite all the migration and infrastructure policies supported since the military government, and despite all the recent enforcement measures promoted by the PPCDAm, the deep Amazon - the area we study in this paper - is still very much a frontier region. Cattle ranchers and illegal loggers are still active. "At the end of the road, on the Amazonian frontier, it feels like the Wild West, except with motor bikes and cell phones," wrote the Vice President and Chief Scientist of WWF, Jon Hoekstra, back in 2010. ${ }^{24}$ In an interview to the New York Times in 2014, a top official of IBAMA, Luciano Evaristo, said about one county black listed

\footnotetext{
${ }^{24}$ http://blog.nature.org/conservancy/2010/05/18/stopping-deforestation-on-the-amazonian-frontier/
} 
by the government, Novo Progresso (literal translation New Progress): "this is the Wild West of environmental crimes. We are waging an endless war." 25

\section{B.3.3 The second reversal}

The driving forces of the reversal we observe starting in 2014 cannot be mapped to a single policy or de jure regulatory change. Brazilian environmental governance was undermined over the years since 2011 by the growing political power of the agriculture producers, consecutive weak governments and scarce public resources. ${ }^{26}$

Political support for the environmental agenda. The loosening of environmental agenda began in 2011 with President Rousseff's first mandate. The new government adopted a more conservative environmental position relative to the previous year, with a greater focus on promoting economic development through large investments in infrastructure. ${ }^{27}$ As Viola and Franchini (2017, Ch. 5) describes, the "Rousseff administration displayed a visible neglect for forest-related and environmental issues". The growing political power of the "ruralists" - i.e., the rural caucus of Congress (Rochedo et al., 2018) - also contributed to the reduced political will to sustain and advance the environmental agenda of the previous years. The number of congressmen in the "ruralists" caucus had grown to 142 in the 2011-2014 legislature - 28\% of the seats - from 116 and 79 in the previous two legislatures. The ruralists continued to grow and to push an environmental deregulation agenda in 2015, when this political group elected 207 congressmen - 38\% of the Congress (Crouzeilles et al., 2017; Freitas et al., 2018)

Background economic and political turmoil. The widespread social mobilizations in 2013 set the government in crisis, which was fired with a series of corruption scandals involving all levels of the Workers Party administration (Viola and Franchini, 2017). As 2014 was an election year, the government increased public spending to gain the popular support needed for re-election. These economic measures helped re-elect Ms. Rousseff but deteriorated the fiscal situation of the federal government, setting the country in its worst economic crisis ever. Brazilian GDP shrank by $3.7 \%$ in 2015 and by $3.5 \%$ in 2016 . Unemployment rate surged quickly. The focus of the federal government shifted to control the economic crisis and the consequences of the corruption scandals. In such unstable political scenario, Ms. Rousseff was impeached by the congress in 2016. The new president Michel Temer was the former vice-president and also involved in the alleged corruption schemes. With very thin public support, the new president had to accommodate the demands from his supporters in congress, in particular, the ruralist caucus.

Environmental regulation. As consequence of this political shift, the congress approved

\footnotetext{
${ }^{25}$ http://www.nytimes.com/2014/10/04/world/americas/brazil-rainforest-amazon-conservation-electionrousseff-silva.html? $\mathrm{r}=0$

${ }^{26}$ See, e.g., Tollefson (2016); Fearnside (2016); Viola and Franchini (2017); Crouzeilles et al. (2017); Rochedo et al. (2018); Freitas et al. (2018); Soterroni et al. (2018); Tollefson (2018).

${ }^{27}$ Still in President Lula's government, Ms. Rousseff had an investment agenda to promote growth (Plano de Acelera;'ao do Crescimento, PAC) and was an antagonist of Ms. Marina Silva, the Minister of Environment who led PPCDAm. Ms. Silva eventually left the government and the Workers Party, while Ms. Rousseff was chosen the Workers Party's candidate on the 2010 presidential election.
} 
of the New Forest Code (FC) in 2012 - Law 12.651/2012. This is the main change in environmental regulation in the period. The revised FC had many controvert points, one of them the forgiven of "small" properties (those with less than 440 ha in the Amazon) that had deforested before 2008 beyond the maximum allowed by PPCDAm. This effectively would give amnesty to illegal deforestation inside private properties for $90 \%$ of Brazilian rural properties, with potential impact of reducing the Brazilian environmental debt by 58\% (Soares-Filho et al., 2014). Another contested point, the authorization of exploitation of Areas of Permanent Protection (APP), such as riparian zones, was decentralized from the federal to the state governments. The constitutionality of different items of the new FC were contested in the Supreme Court already in 2013. The FC stayed under analysis until 2018, when the Supreme Court sanctioned the New Forestry Code, including the amnesty item. After 2012, congress made repeated efforts to undo key aspects of the regulatory framework - for example, the revoke of protected areas, and the discontinuation of environmental licensing for infrastructure projects (PEC 65). In 2017, the congress approved a law (no. 3.465/2017) simplifying the requirements for land regularization and titling of occupied public land in rural and urban areas. Rural smallholders that settled in unclaimed lands before December 2016 could obtain land title for free, while larger properties had the option to pay for the land title.

Enforcement capacity. The resources available to IBAMA (the Environmental Regulatory Agency) to enforce environmental regulation were trimmed over the years. An audit from the Office of the Comptroller General (CGU, 2016) document that the number of IBAMA's enforcement officers fell 13.1\% between 2010 and 2012, and fell $24 \%$ between 2010 and 2014 . The report also attend that the officers still working in 2016 tend to be older - 38\% of them had been working at IBAMA for more than 30 years. Figure A 8 also shows that the budget of IBAMA was cut by $34.2 \%$ between 2013 and 2014. During the two years of Ms. Rousseff second mandate, IBAMA's budget was cut additional $13.5 \%$ relative to 2014 . In 2016, the budget of IBAMA was 57 percent of its budget in 2013.

Thus, more than the de jure impact of the new FC, the "amnesty afforded by the new FC could lead to the perception that illegal deforesters are unlikely to be prosecuted and may even be exonerated in future law reforms" (Soares-Filho et al., 2014, pg.364). This perception should have been reinforced by the deterioration of enforcement apparel. Although it is difficult to map how the New Forest Code or the constrained enforcement capacity of IBAMA affected deforestation in each type of land, our results in Figure 5b indicate a trend reversal starting in 2012 specially in private properties and unclaimed lands. The average point estimate of the differential impact of Brazilian policies in private properties that abut the national borders is 81\% larger in the 2014-2018 period than in 2009-2011.

\section{B.3.4 The formation of the Brazilian border}

Since we focus on the Brazilian border, it is useful to understand briefly the history of how the border was drawn. The broad limits of the Brazilian territory were defined in the colonial period when the Portuguese and the Spanish Crowns had very limited knowledge about the 


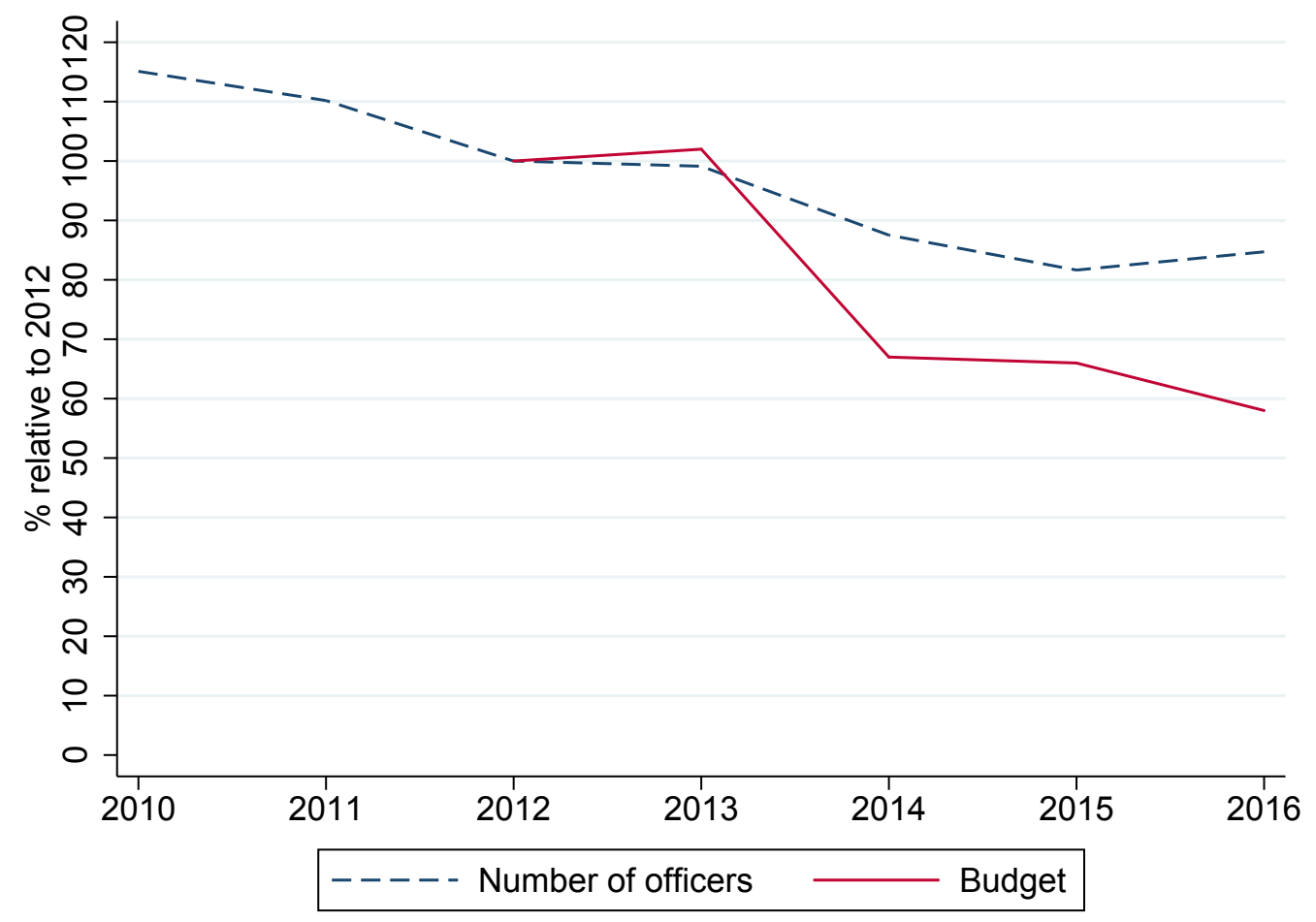

Figure A8: IBAMA's budget and number of enforcement officers over time(CGU, 2016)

precise geography of the center of the South American continent. As such, they usually do not correspond to major differences in economic opportunity - and as we will see, include many arbitrary straight-line segments.

The Treaty of Madrid defined the general lines of the Portuguese - Brazilian - border with the Spanish colonies in 1750. When drawing the Treaty of Madrid map, Portugal and Spain agreed on two general guidelines: (i) who had first established local presence should keep the area (uti possidetis); (ii) rivers should be used as border divisions as much as possible to easy demarcation. The main objective of Portugal during the negotiations was to hold the control of the (known) mining regions located between the center of the continent and the Atlantic coast, pushing the border West to keep potential invaders away. The main objective of the Spanish crown was to maintain navigable access to the sea. As such, the Treaty of Madrid set the limits of the colonies in that region would be defined by the Paraguay and Guaporé Rivers, which are located more than $200 \mathrm{~km}$ and more than $500 \mathrm{~km}$, respectively, from the Portuguese westernmost important settlement, Cuiabá.

At the time, in the middle of the 18th century, the areas in the center of the South American continent - and which form the borders we study today - were still largely unknown. This was particularly true for the Amazon area and the Northern segment of the Brazilian border. Indeed, the magnitude of this "unknown" land can be seen by the vast blank spaces in the base map used in the Treaty of Madrid: Carte de l'Amérique Méridionale. ${ }^{28}$ In fact, the precise location of rivers' springs and mouths - and what was between them - was not exact. The straight-line

\footnotetext{
28“[The] Carte de l'Amérique Méridionale shows, with great detail and many new local circumstances, the empty state of our knowledge with large completely naked spaces" (D'Anville (1779)).
} 
segments we can see in the Brazilian border are a consequence of this lack of information. These are due to rivers that followed a different path than the predicted one or that ended before reaching other geographic feature - and in such cases, the Treaty of Madrid (and the subsequent 1867 Treaty of Ayacucho) specified that a straight line should be used instead. ${ }^{29}$

\footnotetext{
${ }^{29}$ Article VI of the Treaty of Madrid says "... and, from there, seek the straight line by higher ground to the main head of the more nearby river, which flows into the Paraguay River for its Eastern bank, which might be what they call Corrientes." The Treaty of Ayacucho (1867) that defined the precise border between Brazil and Bolivia, more than 100 years later, writes: "This river to the West follow the border by a parallel, taken from the left bank in South latitude $10^{\circ} 20^{\prime}$ until you find the Javary River. If Javary River has its sources North from this East-West line, follow the border, from the same latitude, for a line to get the main source of said Javary.".
} 